\title{
Legal and Practical Challenges of Combating Illicit Trade of Tobacco in Poland
}

\author{
Konrad Buczkowski and Paweł Dziekański
}

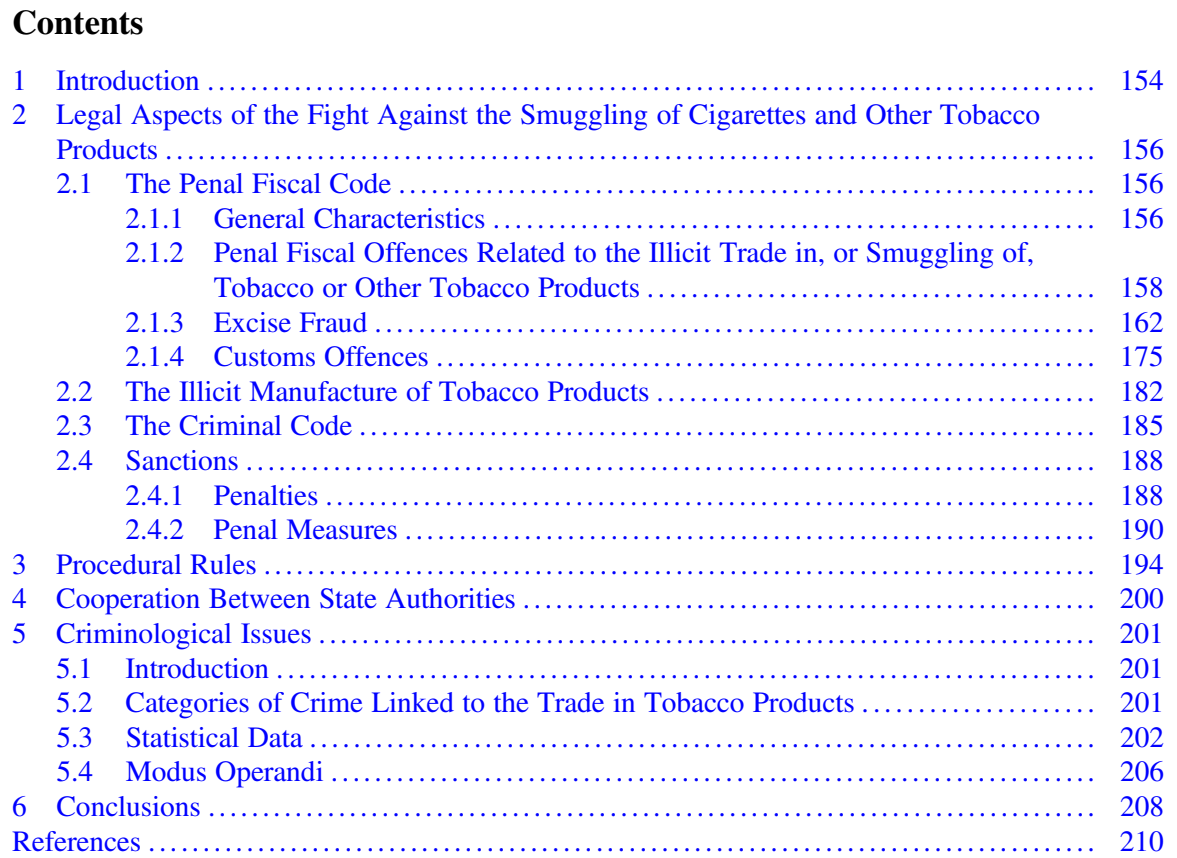

\footnotetext{
K. Buczkowski $(\bowtie)$

Institute of Law Studies, Polish Academy of Sciences, Department of Criminology, Warsaw,

Poland

e-mail: k.buczkowski@inp.pan.pl

P. Dziekański

Institute of Law Studies, Polish Academy of Sciences, Department of Criminal Law, Warsaw, Poland

e-mail: p.dziekanski@inp.pan.pl 


\begin{abstract}
This chapter focuses on the analysis of four main criminal aspects of smuggling in Poland. The first part presents criminal law regulations including regulations on fiscal offences. It was necessary to show criminal reacquisition measures as a result of this kind of crimes. Next, the issues procedural rules with very important matter like international cooperation between authorities to combat global illicit trade. The last part allow to understand the phenomenon of illicit trade of tobacco products, modus operandi and provide basic data on smuggling in Poland.
\end{abstract}

\title{
1 Introduction
}

The WHO Framework Convention on Tobacco Control (hereinafter FCTC) defines the concept of illicit trade in cigarettes and other tobacco products indicating that it means any practice or conduct prohibited by law relating to manufacture, shipment, receipt, possession, distribution, sale or purchase, including any practice or conduct intended to facilitate such activity (Article 1(a) FCTC).

The FCTC Convention focuses on international cooperation to reduce tobacco use by emphasising its harmful effects on health. However, this act contains regulations concerning the area of criminal law. It is assumed that the fight against illicit trade in tobacco products reduces the supply of such products. This thesis, however, stemming directly from the FCTC, needs further investigation and an answer to the question of whether existing criminal law instruments contribute to reducing the demand for cigarettes and other tobacco products. Two situations should be distinguished. Criminal law provisions can be an important factor in the fight against the grey market in tobacco products and can lead to an effective reduction in the volume of products derived from illegal production or smuggling.

The illicit tobacco market is the result of, on the one hand, a desire to avoid the high tax burdens that are imposed on such products. It is estimated that the tax on the price of one pack of cigarettes oscillates around $80 \%$. This is one of the reasons why criminal activity in this area is so lucrative. It is also pointed out that economic crime related to the extortion of tax on goods and services, evasion of excise duty and customs duty is, alongside the production and trafficking in narcotics, one of the most profitable activities of criminal groups. On the other hand, in view of the high prices of cigarettes and other tobacco products, products from illegal sources are popular because of their competitiveness. It should be noted here that available studies show a trend that regular cigarette smoking is more common among people with poor material circumstances (37\% of men, $23 \%$ of women smokers), while the highest percentage of regular smokers is among the unemployed (53\% of men, $41 \%$ of women). For comparison, among people with good material status, the number of men who smoke regularly is $23 \%$, while that of women is $21 \%$. ${ }^{1}$ Criminal repressive

\footnotetext{
${ }^{1}$ Trząsalska et al. (2017), p. 11.
} 
measures, however, are not, and cannot even be, an instrument for reducing the need to use this type of product. Such an objective should be pursued through educational campaigns to raise public awareness in promoting healthy lifestyles and to highlight the harm caused by smoking cigarettes or other tobacco products. Although, in the light of the same studies, respondents indicated that one of the most important factors limiting smoking was increasing the price of cigarettes (65\% of respondents), doubts were raised as to whether it was effective. The share of the grey tobacco market in Poland is at a high level, much higher than in the European Union as a whole. Criminal law instruments should therefore be designed in such a way that they can lead to the elimination or significant reduction in the grey market in tobacco products, for which organised crime is largely responsible. Only the elimination of much of the grey tobacco market, i.e. the unavailability of illegal products, can make the price of a pack of cigarettes or other tobacco products a real factor in reducing the supply of cigarettes or other tobacco products.

The smuggling of cigarettes and other tobacco products is facilitated by the huge differences in cigarette prices across the European Union. This difference can be as much as four times. The differences occur mainly between the eastern and western countries of the EU. This also indicates the direction of cigarette smuggling. However, differences, although slightly lower, also exist in cigarette prices between countries such as Spain, Italy, and the UK, Ireland, France. For example, in 2017 the highest retail price of a pack of 20 cigarettes (converted into British pounds) was recorded in the UK at $£ 9.91$, the lowest in Bulgaria at $£ 2.32$. In Poland, the amount was $£ 2.81$, in Spain $£ 3.93$, Italy $£ 4.37$, Ireland $£ 9.15$, and France $£ 5.67 .^{2}$

Polish criminal law provisions with respect to the issues addressed in this paper are not focused on the notion of illicit trade in cigarettes and other tobacco products. Although the comprehensive collection of individual provisions and the determination of their normative scope allow us to state that the Polish legislator provides for sanctions for the overwhelming majority of activities falling within the definition of illicit trade in the FCTC Convention (Article 1(a)), it does so with the fiscal perspective of the State Treasury and the European Union in mind. The provisions therefore mainly address the issue of the avoidance of the tax that would occur if the goods were legally traded. This approach of the legislator is understandable in the light of the fact that tens of billions of zloty in tobacco excise tax is received annually by the state budget. These products occupy a leading position in the structure of excise revenues. ${ }^{3}$ However, this does not mean that existing fiscal offences legislation is an effective instrument in the prevention of criminal phenomena linked to the illicit manufacture of, or trade in, cigarettes or tobacco products. The concept of illicit trade, as defined in the FCTC, is not transferable to criminal law. It is

\footnotetext{
${ }^{2}$ www.statista.com/statistics/415034/cigarette-prices-across-europe/. (Retail price of a premium pack of 20 cigarettes in selected European countries in 2017).

${ }^{3}$ For example, in 2017, tobacco excise revenues amounted to 18.8 billion PLN (compared to 68.8 billion PLN of total excise revenues), which gave second place in the structure of excise revenues (only motor fuels reached a higher level); see Szajner (2018), p. 3.
} 
characterized by a high degree of ambiguity. There is also a lack of clear criteria for linking individual behaviours to illicit trade, and for determining at what stage it is already possible to talk about such trade.

In systematizing Polish criminal law regulations concerning the illicit trade in cigarettes or tobacco products, their smuggling, or illegal production, we can distinguish: (1) regulations on fiscal offences regarding excise tax and VAT; (2) regulations on fiscal offences regarding customs law; (3) criminal regulations concerning the illegal manufacture of tobacco products; (4) criminal law regulations. This is because it cannot be ruled out that the perpetrators of acts related to the illicit trade in cigarettes or other tobacco products may carry out the elements of crimes stipulated in the Criminal Code. Of course, this classification has been developed for the purposes of this report and has been prepared on the basis of the types of crimes that are related to the illicit activities in question. In making this distinction and in citing and presenting specific crimes in the next section, the theoretical assumptions and available or acquired empirical data were taken into account.

\section{Legal Aspects of the Fight Against the Smuggling of Cigarettes and Other Tobacco Products}

\subsection{The Penal Fiscal Code}

\subsubsection{General Characteristics}

In Poland, penal fiscal law is a part of the criminal law system, but it retains its autonomy. The act referred to above confirmed the specific concept of separating crimes and offences related to the areas of tax law and customs law. There is no space for an historical analyses in this study. However, it seems that a glance into the past shows the gradual development of the concept in Polish legislation that penal fiscal law is an autonomous field of criminal law. Like any theory, this one also has its opponents. The systematisation of crimes against the fiscal interests of the state in a single act took place before the Second World War (the act of 2nd August, 1926). This kind of solution is rare in other legal systems. This is because criminal provisions detrimental to the financial interest of the state are included in individual acts regulating tax and customs law. This type of legislative technique consisting of introducing criminal provisions into acts regulating specific areas of law (so-called industry acts) is known to the Polish legal system, but it is not applicable in the penal fiscal area. An example of such solutions can also be encountered in relation to the issue which is the subject of this report (e.g. the provisions concerning the illicit manufacture of tobacco products are contained in a so-called industry act, which in the following section is included in the second group of the proposed system in the previous paragraph). Without going into detailed considerations referring to the concept adopted by the Polish legislator, it should be stated that penal fiscal law is a specific, separate field of Polish criminal law, in particular it does not constitute 
non-statutory criminal law. ${ }^{4}$ This should be adopted in the light of the nature of the regulations of the Penal Fiscal Code. Examples illustrating the above thesis will be provided later in this study. The legislator himself, in the justification of the draft to the Penal Fiscal Code, indicated that the separateness of this legal act is dictated by tradition and the financial object of the regulation's character. ${ }^{5}$ However, it will be necessary to critically evaluate the effectiveness of such a solution by posing the question whether the Penal Fiscal Code really meets the challenge of taking into account the financial specificity of the institutions concerned, the construction of individual taxes, the specificity of activities, and economic turnover in a given field. For obvious reasons, the analyses in this respect will be limited to excise duties on tobacco products, or possibly to selected issues related to VAT.

The Polish Penal Fiscal Code ${ }^{6}$ (hereinafter: PFC) encompasses the material, legal, procedural and executive aspects. The first of these best expresses this separate character of the regulations. The principles of criminal liability for fiscal offences have been developed independently of the Criminal Code $^{7}$ (hereinafter: CC). This is confirmed by the provision of article $20, \S 1$ of the PFC, stating that the provisions of the general part and Chapter XXXVIII of the Criminal Code (general provisions concerning soldiers) do not apply to fiscal offences, except for the provisions expressly indicated in Article 20, $\S 2$ of the PFC. The aforementioned Article $20, \S 1$ of the PFC in fact excludes the application of the provisions of the general part of the Criminal Code which, in accordance with the principle in article 116 of the $\mathrm{CC}$, applies to other acts providing for criminal liability, unless these acts expressly exclude their application. The provision of article $20, \S 1$ of the PFC performs such a function. At this point, it must become clear that, unlike general criminal law offences, fiscal crimes or offences are not found in other laws. The Penal Fiscal Code stipulates all fiscal offences and misdemeanours. On the one hand, the complexity of codification can be considered an important advantage. On the other hand, however, there are some doubts as to whether the types of fiscal offences take into account the specificity of excise tax, and generally also other tax constructions, including changes in excise tax regulations. The assumption is that the Penal Fiscal Code is to take into account the specificity of its normative scope, and adopt tax and civil law constructions. In addition, it is to change the approach to punishment placing the main emphasis on the penalty of a fine, the financial nature of criminal repression. However, in practice there are many problems that call into question the thesis that the assumptions of the Penal Fiscal Code quoted above have been fulfilled or are even accurate. Some of them will be indicated in the further sections of this study.

\footnotetext{
${ }^{4}$ See also: Prusak and Skowronek (2018), pp. 7-9.

5 Justification to the government's bill on the Penal Fiscal Code, Sejm of the 3rd term, print No. 1146, http://orka.sejm.gov.pl/Rejestrd.nsf/wgdruku/1146/\$file/1146.pdf.

${ }^{6}$ The act of 10th September, 1999-Penal Fiscal Code (i.e. Journal of Laws of 2020, item 19, as amended).

${ }^{7}$ The act of 6th June, 1997— the Criminal Code (Journal of Laws of 2019, item 1950, as amended).
} 
In article 46 of the PFC the assumption was adopted that the provisions of the general part of the Code of Administrative Offences shall not apply to fiscal offences. $^{8}$ In this case, the Penal Fiscal Code does not make any breakthrough in the principle of autonomy, as it was done in the area of fiscal offences by allowing appropriate application of certain provisions of the general part of the Criminal Code, which was mentioned earlier. Such a solution can be justified on at least two grounds. Firstly, for fiscal offences, certain provisions on liability for fiscal offences will apply. The provisions of the general part included in Chapter 1 "Preliminary provisions", Chapter 2 "Refraining from punishing an offender" (article 1-19 of the PFC) are applicable to fiscal offences and, obviously, Chapter 3 "Fiscal offences" (article 46-52 of the PFC). Secondly, the nature of fiscal offences should be highlighted. The overwhelming majority of them refer to the features describing the causal activity of particular fiscal crimes. In such cases, the determination of whether we are dealing with a crime or a fiscal offence is limited to the amount of tax liable to be depleted. If it does not exceed the statutory threshold, i.e. five times the minimum remuneration at the time of committing the act (article 53, $\S 6$ of the PFC in conjunction with article 53, $\$ 3$ of the PFC), the act constitutes an offence. The second, smaller, part of offences in the Penal Fiscal Code is no longer determined by the aforementioned limit, but by a clear statutory indication. In accordance with article 53, $\$ 3$ in fine of the PFC, a fiscal offence is also any another act if the Code so provides.

\subsubsection{Penal Fiscal Offences Related to the Illicit Trade in, or Smuggling of, Tobacco or Other Tobacco Products}

The provision of article $54, \S 1$ of the PFC states that a taxpayer who evades taxation and fails to disclose to the competent authority the subject or taxable base or does not submit a declaration, thus exposing the tax to depletion, is subject to the penalty of a fine of up to 720 daily rates or the penalty of deprivation of liberty, or both these for a privileged type of crime described above. The perpetrator is more leniently liablethe act is punishable only by a fine of up to 720 daily rates, if the amount of tax liable to depletion is small. However, in article 54, $\S 3$ of the PFC we find a penalties jointly. This act constitutes a fiscal offence. This is the basic type of tax evasion offence, where the subject or taxable base is not disclosed or a tax return is not filed. Article 54, § 2 of the PFC provides for a fiscal offence consisting of the execution of the elements of the act described in article 54, $\$ 1$ of the PFC, but the exposure to tax depletion does not exceed the statutory threshold. A consequence of being included in the elements of a crime under article 54 of the PFC is therefore a symptom which allows one to distinguish the type of a privileged crime, as well as a fiscal offence. This type of construction falls under the jurisdiction of the Polish Penal Fiscal Code,

\footnotetext{
${ }^{8}$ The act of 20th May, 1971 - the Code of Administrative Offences (i.e. Journal of Laws of 2019, item 821 , as amended).
} 
which has already been noted. This provision, although it does not refer anywhere to the phenomenon of illicit trade in cigarettes, tobacco and excise duties, is often used to combat crime associated with the activity in question. The behaviour of a taxpayer who evades taxation or does not submit a return, thereby exposing the tax to depletion, will relate to those situations in which he markets or transports cigarettes or other tobacco products. Nonetheless, due to the fact that the structure of excise duty includes situations where no tax liability arises in the Republic of Poland, while simultaneously a person is involved in illicit trade in illicit cigarettes or other tobacco products, in the light of article 54 of the PFC, it must be established each time that a specific person is subject to a tax obligation resulting from a specific tax act (article $7, \S 1$ of the Tax Code), as this results from the legal definition of a taxpayer under the Penal Fiscal Code (article 53, $\$ 30$ of the PFC and article 53, §30a of the PFC). The indicator of a taxpayer used in article 54, $\S 1$ of the PFC is a generalised indicator. Its determination requires not only finding the source of the tax obligation, but also stating that in this particular factual state this obligation existed (there are certain doubts in this respect in the case of the procedure for the suspension of excise duty collection). If the procedural authorities fail to prove this, criminal liability for the above mentioned act will not be possible.

Notwithstanding the fact that there are problems with the fact that not every person involved in the illicit trade in cigarettes or tobacco may be considered a taxable person, there are also situations where the taxable person within the meaning of the aforementioned provisions is not a natural person but a legal person. In such a case, the fiscal liability may be incurred only in the case described in article $9, \S 3$ of the PFC. It shall apply to a person who, on the basis of a provision of law, a decision of a competent authority, a contract or actual execution, deals with economic matters, in particular financial matters, a natural person, a legal person or an organisational unit without legal personality. These circumstances require evidence to be established. Within the framework of the analysed type of crime, very often, especially within the framework of organised crime, we are dealing with the creation of fictitious legal entities, involving random persons, a so-called "front man", who takes on (often unconsciously or not knowing about the essence or size of the criminal activity) the functions associated with certain obligations in the tax sphere. This makes it impossible or very difficult in reality to capture and prosecute the actual perpetrators. 9

The question is whether the subject of taxation within the meaning of article $54, \S 1$ of the PFC are products derived from illegal activities. Similar doubts apply to article 56 of the PFC. Both these provisions may give rise to fiscal liability for activities connected with the smuggling of cigarettes or other tobacco products. These crimes are commonly referred to as tax fraud. They concern both value added tax and excise tax.

\footnotetext{
${ }^{9}$ Buczkowski, Przestępstwa skarbowe jako czyny bazowe w konstrukcji prania pieniędzy (2013), pp. 1117-1152.
} 
The provision of article $56, \S 1$ of the PFC stipulates that a taxpayer who, by submitting a declaration or statement to the tax authority, other authorised body or payer, gives untrue information or conceals the truth or fails to fulfil the obligation to notify about a change of data covered by it, thus exposing the tax to depletion, is subject to a fine of up to 720 daily rates or a penalty of deprivation of liberty, or both these penalties jointly. Similarly to article 54 of the PFC, the following paragraphs of article 56 of the PFC, i.e. $\S 2$ and $\S 3$ introduce, respectively, a privileged type of fiscal crime consisting of exposure to low value tax depletion and a fiscal misdemeanour concerning such exposure to tax depletion if it does not exceed the statutory threshold. Additionally, article 56, $\$ 4$ of the PFC provides for a fiscal offence consisting of not submitting a tax return or declaration on time to the tax authority or payer or in breach of the obligation not to submit them by electronic means of communication. The provision of article 56, $\S 4$ of the PFC provides for the same penalty as for an offence under article $56, \S 3$ of the PFC. In the case of excise tax, it is the case that a taxpayer submits a number of declarations to the tax authority (article 21 of the Excise Tax Act) in cases where tax liabilities arise in the event of the existence of the events specified in the act (such is indicated in article 8 of the Excise Tax Act). ${ }^{10}$ A taxpayer is obliged to identify and declare the amount of tax liabilities on its own. In such a state of affairs, the provision of article 56 of the PFC is a standard securing the execution of tax liabilities. There is no doubt that it refers to taxpayers who make fraudulent reporting procedures with respect to the extent of their obligations under the Excise Duty Act. The Constitutional Tribunal ruled on the compatibility of the article with the Constitution of the Republic of Poland, while commenting on the proportionality and the need for the functioning of this provision, indicating that the establishment of sanctions for breach of record-keeping obligations is not only allowed, but necessary to ensure equality and universality of taxation. ${ }^{11}$ It should be remembered that acts under article 56 of the PFC are material crimes. In order to bring the perpetrator to justice it is not sufficient to establish the behaviour of the taxpayer in terms of one of the modal features, but it is necessary to establish the effect of exposure to a reduction in tax.

At this point, it is necessary to make a few remarks concerning the act described in article 76 of the PFC. It can be seen as a complement to the crime under article 56 of the PFC, which, due to the way its constituent elements are formulated, does not refer to facts including annoying criminal practice related to obtaining a tax refund. In practice, there are often cases in which an important issue is the issue of separating whether the perpetrator commits a crime under article 56 of the PFC or article 76 of the PFC. The decisive factor in this respect is the assessment of the party concerned. The provision of article $76, \S 1$ of the PFC states that anyone who, by providing data inconsistent with the actual state of affairs or concealing the actual state of affairs, misleads the competent authority by exposing it to undue tax refund

\footnotetext{
${ }^{10}$ The act of 6th December, 2008, on Excise Duty (i.e. Journal of Laws of 2020, item 722).

${ }^{11}$ Judgement of the Constitutional Court of 12th September, 2005, Case No. SK 13/05, LEX No. 165330.
} 
of public-law receivables, in particular input tax within the meaning of the provisions on value added tax, excise tax, refund of overpayment or its crediting towards tax arrears or current or future tax liabilities, is subject to a fine of up to 720 daily rates or a penalty of deprivation of liberty, or both these penalties jointly. Article 76, § 2 of the PFC introduced a type of privileged offence, if the amount exposed to undue tax refund is of low value, the perpetrator of the prohibited act specified in article $76, \S 1$ of the PFC is subject to a fine of up to 720 daily rates. Article $76, \S 3$ of the PFC stipulates that an offence shall be punishable by a penalty. According to the construction already discussed, if the amount exposed to undue tax refund does not exceed the statutory threshold, the perpetrator of the prohibited act specified in article $76, \S 1$ of the PFC is subject to a penalty as for a fiscal offence.

The problem indicated in the introduction to the discussion on articles 54 and 56 of the PFC, on whether illegal activities or activities related to such products may be subject to taxation, is of significant importance for the issue to be addressed in the study. The Supreme Court in its decision of 22nd November, 2011, file ref. No. IV KK 270/11, ${ }^{12}$ indicated that the Excise Duty Act does not introduce any additional requirements for obtaining the status of an excise tax payer. It has been pointed out that article 8 of the same act, when calculating the activities subject to excise duty, does not make distinctions for two situations: their execution "legally" or "illegally". It was considered that this argument already demonstrates that each of these behaviours is subject to excise duty. This is related to the specific nature of excise duty. Its construction entitles one to make the thesis that anyone who performs certain activities giving rise to tax liability is a taxpayer. Therefore, if an activity-even a criminal activity - corresponds in its content to an activity that is subject to excise duty, then a tax obligation arises. The position, also presented in the aforementioned ruling, is correct, namely that while procedures involving, for example, drug trafficking or prostitution cannot be taxed, those activities that were illegal, but could be carried out as legal, should be subject to taxation. An analogous position is clearly expressed in the case law of the Court of Justice of the European Union, which draws attention to a very important aspect of the problem - the competitiveness of products. In several judgements, the Court has pointed out that no distinction can be drawn between activities carried out lawfully or illegally if they are capable of competing on the market. ${ }^{13}$ This is the case, for example, with cigarettes that have been legally placed on the market and counterfeit cigarettes from illegal production or smuggling. Although the CJEU rulings relate to value added tax, these considerations should also apply to excise duty. Taking the opposite view would lead to better treatment of products coming from illegal sources and the avoidance of fiscal liability by the persons who, in fact, carry out the activities that create the tax obligations.

\footnotetext{
${ }^{12}$ Legalis No. 509576.

${ }^{13}$ Judgement C-3/97 of 28th May, 1998 in J.C. Goodwin and E.T. Unstead, CELEX No. 61997CJ0003; judgement C-455-98 of 29th June, 2000 in Karpo Salmets and Others, CELEX No. 61998J0455.
} 


\subsubsection{Excise Fraud}

We will now move on to a discussion of the group of fiscal offences and crimes known as excise offences. So far, crimes related to all taxes have been described, including naturally excise taxes and VAT. One of the significant problems of Polish criminal law in relation to the problem raised is the fact that a range of crimes has been foreseen which potentially relate to the issue of illegal production, smuggling or trade in tobacco products. We are referring here to a particularly large group of excise offences in the Penal Fiscal Code, which may concern various behaviours occurring at various stages of the procedure under discussion. However, in practice these provisions are not used, often confining themselves to the use of the discussed article 54 of the PFC. The issue of criminal activities related to the illicit trade in tobacco products is thus reduced solely to the issue of tax evasion. Regardless of this approach, a group of excise offences must be presented in this study as the bulk of them relate to this type of crime, especially if we accept the definition of the FCTC or recognise the need for a broad understanding of the concepts of illicit trade, smuggling, or illicit manufacture.

The provision of article $63, \S 1$ of the PFC stipulates that whoever, contrary to the provisions of the act, issues excise goods in relation to which the excise duty suspension procedure has been completed, without prior marking with excise duty markings, shall be subject to the penalty of a fine of up to 720 daily rates or the penalty of deprivation of liberty for up to 2 years, or both of these penalties jointly. This provision contains a clause referring to the Excise Duty Act. Only conduct that violates the individual provisions of the Tax Act is subject to criminal liability. Tobacco products are one of the basic categories of excise goods (article 2, paragraph 1, point 1 of the Excise Duty Act). The source of the definition of tobacco products is Directive 2011/64/EU (merging Directives 95/59 EC, 92/79/EEC, and 92/80/ EEC). ${ }^{14}$ Article 98 of the Excise Duty Act contains the list of tobacco products. Excise duty suspension arrangements are defined in article 4, point 7 of Directive 2008/118//EEC as "a tax arrangement applicable to the production, processing, holding or movement of excise goods not placed under a customs suspensive procedure or arrangement where excise duty is suspended". ${ }^{15}$ This definition has been transposed into national law. In accordance with article 2, paragraph 1, point 12 of the Excise Duty Act, it means a procedure applied during the production, storage, handling and movement of excise goods, during which, when the conditions set out in the provisions of the Excise Duty Act and in the implementing acts issued on its basis are fulfilled, no tax liability arises from a tax obligation. Excise duty becomes due at the time of release for consumption (article 7 of Directive 2008/118// EEC). Thus, under a duty suspension arrangement, the tax is levied and collected in

\footnotetext{
${ }^{14}$ Council Directive 2011/64/EU of 21st June, 2011, on the structure and rates of excise duty applied to tobacco products, OJ L 176/24 of 5/07/2011.

${ }^{15}$ Council Directive 2008/118/EC of 16th December, 2008 concerning the general principles of excise duty and repealing Directive 92/12/EEC, OJ L 9/12 of 14/01/2009.
} 
the EU Member State where the product is intended for consumption. The main assumption of the procedure is therefore to shift the obligation to pay the tax in such a way that it does not take place during production but at the moment of release for consumption and in the country where the product is released for consumption. The excise duty suspension procedure applies to so-called community goods. The end of the excise duty suspension arrangement actually means release for consumption. The provisions of article 42, paragraph 1 and article 44, paragraph 1 of the Excise Duty Act provide an exhaustive list of cases in which the procedure is terminated. Excise markings are markings specified by the minister in charge of public finances, used to mark excise goods subject to the obligation to be marked, including: excise tax markings, which confirm payment of the amount constituting the value of excise tax markings; legalisation excise tax markings, which confirm the right of an entity obliged to mark excise goods with excise tax markings, to designate those goods for sale (article 2, paragraph 1, point 17 of the Excise Duty Act). Cigarettes, tobacco for smoking, cigars and cigarillos and dried tobacco are products subject to the obligation to bear excise duty markings (article 114 of the Excise Duty Act and Annex 3 thereto). Excise goods that have not been marked, are incorrectly marked or marked with incorrect markings cannot be marketed (see the obligations to mark contained articles 116 and 117 of the Excise Duty Act). Therefore, this provision of the Penal Fiscal Code sanctions such a ban and this is important for the correctness of the suspended excise duty procedure. It should be noted that activities related to the movement of excise goods, including under the suspended excise duty procedure, are subject to administrative control of the state and are subject to a number of administrative obligations. The criminal law norm not only secures the fact of paying fiscal debts, but also the fact that the product on the market is a fully legal product, released for consumption. Any behaviour involving a change of location or movement of excise goods should be considered as the release of excise goods. ${ }^{16}$ In accordance with article $63, \S 2$ of the PFC, a penalty specified in the discussed article $63, \S 1$ of the PFC is imposed on anyone who, contrary to the provisions of the act, imports excise goods into the territory of the country without prior marking with excise tax markings. The term "imports" covers two groups of behaviours referred to in the Excise Duty Act: (1) importation into the territory of the Republic of Poland of excise goods from countries which are not members of the European Union, i.e. import (article 2, paragraph 1, point 7, subpoint b of the Excise Duty Act); (2) movement of excise goods from the territory of a Member State of the European Union other than the Republic of Poland to its territory, i.e. intra-Community acquisition (article 2, paragraph 1, point 9 of the Excise Duty Act). A discussion of the provision of article $63, \S 3$ of the PFC will be omitted as it does not apply to tobacco products. Article $63, \S 4$ of the PFC stipulates that the same penalty as in article $63, \S 1$ of the PFC is imposed on a person who removes excise goods from a tax warehouse without prior marking with excise duty stamps on the basis of a permit to remove excise goods from someone else's tax warehouse as a taxpayer

\footnotetext{
${ }^{16}$ Łabuda (2017), pp. 721-722.
} 
outside the excise duty suspension procedure. Within the meaning of that provision, removal is to be understood as the physical change in the location of a product constituting an excise product. The procedure of permitting the removal of products from a third-party warehouse is governed by article 54 of the Excise Duty Act. The result is a change of taxpayer. It is no longer the person who runs the tax warehouse, but the person who obtained a decision of an authority allowing it to remove products from someone else's warehouse and it is they who are responsible for obligations secured by the criminal norm resulting from article $63, \S 4$ of the PFC. In accordance with article $63, \S 5$ of the PFC, the penalty specified in article $63, \S 1$ of the PFC is also imposed on a person who commits the behaviours specified in article $63, \S 1-4$ of the PFC in relation to excise goods which have been marked incorrectly or with inappropriate excise duty markings, in particular with damaged, destroyed, counterfeited, forged or invalid markings. The rules and procedure for applying excise markings are laid down in the Excise Duty Act (see article 120) and the ordinance of the Minister of Finance of 7th June, 2019, on the marking of excise goods ${ }^{17}$ with excise markings issued pursuant to article 122 of this act. In view of these regulations, placing a marking in such a way that its removal or opening does not cause damage to the marking, which thus allows its reuse, should be considered as incorrect marking with excise tax markings. It is not appropriate to mark excise goods with excise markings which are not intended for a given excise product. Article 131, paragraph 7 of the Excise Duty Act specifies that damaged excise duty markings are those in which a permanent and visible violation of the physical properties allows identification of markings with respect to their originality, type, name, dimensions, series, registration number and date of manufacture. Article 131, paragraph 8 of the act indicates that the damaged markings are original excise duty markings in which permanent and visible violations of physical properties make it impossible to identify the marking as to its type, name, series, identification number and date of manufacture. Excise duty markings may turn out to be invalid in the event of the introduction of a new design for an excise marking. In such a case, in accordance with article 134, paragraph 1 of the Excise Duty Act, entities holding existing markings are obliged to return the unused markings to the issuing entity within 30 days of the date of the introduction of the new design. In addition, markings affixed before the introduction of the new design are valid for a period of 12 months from the date of the introduction of the new marking (article 134, paragraph 2 of the Excise Duty Act). The notion of counterfeiting and falsification should be given the meaning which these terms have in the Criminal Code (see article 270, § 1 of the Criminal Code). Thus, counterfeit excise duty markings should be considered to be those imitating an authentic marking, coming from an issuer who is not entitled to issue it. Alteration of an excise tax marking relates to changes made to an authentic marking and assumes that the content of the marking will be different

\footnotetext{
${ }^{17}$ Journal of Laws of 2019, item 1147; the ordinance came into force on 19th June, 2019, and replaced the previous ordinance on this subject of 23rd December, 2015, Journal of Laws of 2015, item 2283, as amended.
} 
from the original one. Unlike counterfeiting, alteration does not have to have the characteristics of permanence and non-removability of the changes made. ${ }^{18}$ The provision of article 63, paragraph 6 of the PFC provides for a privileged type with reference to all acts described in $\S 1-5$ of article 63 of the PFC. If the excise duty due is of low value, the perpetrator of the offence is liable to a fine of up to 720 daily rates. However, if the excise tax does not exceed the statutory threshold, the perpetrator of the prohibited act specified in $\S 1-5$ of article 63 of the PFC is subject to a fine for a fiscal offence. Due to an error by the legislator, it is not possible to order forfeiture in regards to all fiscal offences under article 63 of the PFC, types of privileged fiscal offences under article 63 of the PFC, or other fiscal offences if the subject is an excise product incorrectly marked or inadequately marked with excise tax markings with respect to acts committed in the period from 17th October, 1999 (date of entry into force of the Penal Fiscal Code) up to 29th July, 2010 (on 30th July, 2010, the error resulting from the amendment of the Penal Fiscal Code made in the act dated 25th July, 2010, amending the act on tax inspections and certain other acts $^{19}$ ). Forfeiture in the Penal Fiscal Code is adjudicated if the Code provides for this, while the court may pronounce forfeiture only in the cases provided for in the Code (article 30, 1 of the PFC, article $49, \S 1$ of the PFC). As regards the acts referred to, prior to 30th July, 2010, there was no provision allowing for a forfeiture decision (optional or obligatory).

Not all crimes under article 64 of the PFC will be related to tobacco products. The offences in $\S 2-5$ of this article shall not apply to such offences. In this study, only those that are related to the issues under study will be indicated. The provision of article $64, \S 1$ of the PFC states that anyone who, without written notification within the time limit of the competent authority, removes excise goods not marked with excise markings from a tax warehouse for the purpose of making their intracommunity supply or export shall be subject to a fine of up to 720 daily rates. In article 118, paragraph 5 of the Excise Duty Act is the main source of the obligation to notify the competent authority about the removal of excise goods not marked with excise markings from a tax warehouse. In the Excise Duty Act, this situation is understood as an exemption from the obligation to use markings, which applies to specific excise goods and is subject to a written notification to the competent head of the tax office. The cases of exemption from that obligation are indicated not only in article 118 of the Excise Duty Act, but also in the Ordinance of the Minister of Finance of 20th August, 2010, on the exemption of excise goods from the obligation to mark excise goods with excise ${ }^{20}$ markings, which concerns tobacco products, issued pursuant to article 119 of the Excise Duty Act. The provision of article 64, § 6 of the PFC states that the penalty specified in article $64, \S 1$ of the PFC is also imposed on a person who, without written notification to the competent authority,

\footnotetext{
${ }^{18}$ See with respect to the term of alteration, falsification of a document: (Wróbel and Zoll 2017), pp. $695,699$.

${ }^{19}$ Journal of Laws of 2010, No. 127, item 858.

${ }^{20}$ Journal of Laws of 2019, item 2427, as amended.
} 
places excise goods not marked with excise markings, intended for sale in commercial units located there, in a duty free zone without a written notification. The provision of article $64, \S 7$ of the PFC indicates that if the offences specified in $\S$ 1-6 of the same article constitute a minor case, they are fiscal offences. The Penal Fiscal Code defines a legal definition of a minor case in article 53, $\S 8$ of the PFC.- it is a prohibited act as a fiscal offence, which in a specific case, due to its special circumstances-both subjective and objective-contains a low degree of social harmfulness of the act, in particular when the public-law debt depleted or exposed to depletion does not exceed the statutory threshold (article 53, $\S 6$ of the PFC), and the manner and circumstances of committing the prohibited act do not indicate a gross disregard by the perpetrator of the financial and legal order or prudential rules required in given circumstances, or the perpetrator of the prohibited act, where the subject is of low value, does this for reasons that should be taken into consideration. The characteristic of removal should be understood in the same way as in relation to article 63 of the PFC.

Article 65 of the PFC typifies a prohibited act known as the illicit handling of excise goods. In accordance with article $65, \S 1$ of the PFC: whoever acquires, stores, transports, sends or transfers excise goods being the subject of a prohibited act specified in articles 63,64 , or 73 or assists in their disposal, or accepts or assists in their concealment of these excise goods, shall be subject to the penalty of a fine of up to 720 daily rates or the penalty of deprivation of liberty for up to 3 years, or both of these penalties jointly. In article $65, \S 2$ of the PFC we find an unintentional type of this crime ("... of which on the basis of accompanying circumstances one should and may presume that they are the subject of a prohibited act as specified in article 63, 64, 73 ...”), punishable by a fine of up to 720 daily rates. $\S 3$ refers to the type of privileged fiscal crime. If the amount of tax at risk of depletion is low, the perpetrator of the offence specified in $\S 1$ is subject to a fine of up to 720 daily rates. However, if the amount of tax at risk of depletion does not exceed the statutory threshold, the perpetrator of the prohibited act specified in $\S 1$ (intentional handling of excise goods) or $\S 2$ (unintentional handling of excise goods) shall be liable to a fine for a fiscal offence. The act of committing the illicit handling of excise goods was defined very broadly, much more broadly than in the case of the crime of receiving stolen goods (article 291 of the CC, article 292 of the CC). It is expressed in the following characteristic verbs: purchases, stores, transports, sends, transfers, moves, assists in disposal, accepts, assists in concealing. In order to commit an offence of handling excise goods, it is sufficient for the perpetrator to carry out one of the above elements. It cannot be ruled out that the perpetrator will satisfy more of them with his behaviour. These characteristics refer to the illegal acts listed by the legislator, which is a closed list. With respect to the problem of illicit trade in tobacco products, the provision of article 65 of the PFC will not be effective, in particular with respect to activities related to purchasing, storing, transporting, sending, transferring, assisting in disposal, receiving, assisting in concealing cigarettes and other tobacco products derived from illegal production. A person dealing with such a procedure does not fulfil the characteristics of any of the offences listed in article $65, \S 1$ or 2 of the PFC, and therefore it is not possible to recognise on the basis of the provision in 
question that such objects originate from a crime. Although it cannot be excluded that tobacco products may be the subject of certain crimes under articles 63, 64 and 73 of the PFC, these cases are not frequent, all the more so as some of the crimes referred to in these articles concern other excise goods, as already mentioned. However, article 65 of the PFC is not an instrument for combating trade in tobacco products originating from illegal production or smuggling.

The crime of defective marking of a product with excise tax markings has been stipulated in article 66 of the PFC. In accordance with $\S 1$, a fine of up to 720 daily rates is imposed on anyone who incorrectly or inappropriately marks excise goods, in particular with damaged, destroyed, counterfeited, altered or invalidated markings. In cases of lesser significance, the perpetrator of this act is subject to a fine as for a fiscal offence $(\S 2)$. The concepts and basic provisions of the Excise Duty Act in the field of marking of excise goods were discussed earlier in dealing with a crime under article $63, \S 5$ of the PFC. This act did not concern the issue of marking of excise goods, but the undertaking of one of the enforcement activities listed in article $63, \S 1-4$ of the PFC with respect to incorrectly marked excise goods. The presented understanding of the notions of damaged, destroyed, counterfeited, falsified, altered and invalid markings should also be referred to article 66 of the PFC.

It is a criminal offence to falsify excise markings. Whosoever forges or alters an excise marking or authorization to collect an excise marking shall be subject to the penalty of a fine of up to 720 daily rates or the penalty of deprivation of liberty, or both of these penalties jointly (article 67, $\S 1$ of the PFC). The usage of the verbs forge or alter have been discussed in the analysis of article $63, \S 5$ of the PFC. The authorisation to collect excise duty markings is issued by the head of the tax office competent in matters related to excise tax markings (article 128, paragraph 2 of the Excise Duty Act). Such authorisation shall be preceded by a corresponding decision on the issuing of excise tax markings. The provision of $\S 2$ criminalises obtaining or adapting measures in order to commit the fiscal offence specified in article $67, \S 1$ of the PFC. This is liability for preparing for a fiscal crime. This act is punishable by a fine of up to 240 daily rates or by imprisonment for up to 2 years or both jointly. Article $67, \S 3$ of the PFC provides for a special case of active grievance (special with regard to article 16 of the PFC and the requirements stipulated therein): there is no penalty for a fiscal offence defined in article $67, \S 2$ of the PFC for a perpetrator who withdrew from its execution, in particular, destroyed or prevented the acquired or adopted measures or prevented their use in the future. The provision of article $67, \S 4$ of the PFC stipulates that cases of minor importance, the perpetrator of a prohibited act specified in article $67, \S 1$ or 2 of the PFC is subject to a fine for a fiscal offence.

In accordance with article $68, \S 1$ of the PFC, anyone who fails to fulfil the obligation to draw up a list and present it for confirmation to the competent authority in the event of unspecified excise goods marked incorrectly or improperly with excise markings, in particular damaged, destroyed, forged, altered, counterfeited or invalid in circulation outside the excise duty suspension procedure, shall be subject to a fine of up to 720 daily rates. This criminal standard is another one, which is connected with the violation of obligations resulting from the specific nature of the 
trade in excise goods. The provision of article 116 of the Excise Duty Act specifies the entities obliged to mark their products with excise duty markings, and also indicates certain additional obligations, such as the obligation to prepare a list and present it for confirmation to the competent head of the tax office in the event of the possession of unmarked excise goods, excise goods marked incorrectly or excise goods with inappropriate markings. The source of the obligation secured with a punitive sanction under article $68, \S 2$ of the PFC is the provision of article 116, paragraph 3 of the Excise Duty Act. The penalty specified in article 68, $\S$ 1 of the PFC is imposed on a person who does not fulfil the obligation to mark excise goods with legalization excise markings. Article $68, \S 3$ of the PFC states that in cases of minor importance, the perpetrator of a prohibited act specified in article $68, \S 1$ or 2 of the PFC is subject to a fine for a fiscal offence.

The provision of article 69 of the PFC is very important in the fight against the illicit trade in tobacco products. It concerns such behaviours as: undertaking activities directly related to the production, import or trade in excise goods, as well as their marking with excise markings without official verification $(\S 1)$; providing false information on the characteristics of manufactured excise goods $(\$ 2)$; removing excise goods from the place of production, processing, consumption, storage or during transport ( $\$ 3)$. For each of these acts, the perpetrator is liable to a fine of up to 720,360 and 240 daily rates, respectively. Compared to the offences previously discussed, the legislator has not provided for their privileged types or for a case of minor importance constituting an offence. This distinguishes this prohibited act in terms of the assessment of its degree of social harmfulness, of course, in an abstract way. Moreover, article 69, $\$ 4$ of the PFC stipulates punishment for attempting the acts specified in article $69, \S 2$ or 3 of the PFC. "Attempting" in penal fiscal law is punishable by a penalty not exceeding two-thirds of the upper limit of the statutory threat provided for the given fiscal offence (article 21, § 2 of the PFC). The official verification is carried out by an institution specified in the act of 16th November, 2016, on National Treasury Administration, ${ }^{21}$ which belongs to the competence of the head of the customs and fiscal office. It is carried out in the cases and to the extent specified in article 106 of the aforementioned act. Activities related to the production, import and marketing of tobacco products, as well as to their marking, must be carried out within a tax warehouse (Article 47, paragraph 1 of the Excise Duty Act) with the exception of dried tobacco (Article 47, paragraph 1, point 8 of the Excise Duty Act) and the production of excise goods on which advance payment of excise duty has been paid (Article 47, paragraph 1, point 1 of the Excise Duty Act). This means that, with the exception of two exceptions, it is mandatory to carry out an official check.

The act under article $69, \S 2$ of the PFC is related to obligations concerning customs and fiscal control. In the Act on National Treasury Administration (hereinafter: NTA), entities operating in the field of production, import and trade in tobacco products are subject to a number of information obligations (see e.g. article 74 of the

\footnotetext{
${ }^{21}$ Journal of Laws of 2020, item 505, as amended.
} 
NTA Act), article $69, \S 2$ of the PFC criminalises only those behaviours which concern the transfer of data on the quantity and quality of excise goods. It follows from the provision in question expressis verbis that a causative act does not include an omission, but concerns only an act-the provision of false data. This means data that does not correspond to the actual state of affairs. In legal doctrine, a situation in which the perpetrator does not provide data to his disadvantage, i.e. leads to an overstatement of the tax due, is resolved differently. The realisation of the elements of the offence in question may result in a reduction of excise duty or in its undue reimbursement. If we support the view that the Penal Fiscal Code applies the rules of excluding multiple assessments, then in the case of depletion of excise tax only article 56, § 1-3 of the PFC will have to be applied, and in the case of improper reimbursement of excise tax-article 76, § 1-3 of the PFC. Otherwise, the crimes described (article 69, $\S 2$ of the PFC will be in concurrence with article 56, §1-3 of the PFC or article 76, § 1-3 of the PFC) will remain in real concurrence with fiscal offences. In the event that the perpetrator provides untrue data to his disadvantage, which means that it leads to an increase in his tax liability or an understatement of his tax refund, the execution of the elements of article 56, $\S 1-3$ of the PFC or article $76, \S 1-3$ of the PFC should be excluded. In such cases, the lack of liability for the act of article $69, \S 2$ of the PFC is explained by the lack of an impact on the legal good. ${ }^{22}$ However, in the authors' opinion, consideration should be made on how legal goods subject to protection under the Penal Fiscal Code are understood. On the grounds of various fiscal crimes, commentators basically distinguish one legal good-property of the State Treasury, sometimes of the European Union, because the income from taxes goes to the national and European budget. However, the scope of criminalization determined at least by the crimes discussed makes one wonder whether it is correct to reduce the regulations of the Penal Fiscal Code to the protection of legal property consisting solely of the fiscal interest, and also whether it is not possible to distinguish a further and closer subject of protection. Another common view justifying the thesis that the perpetrator is not responsible for providing untruths which leads to a tax overstatement is the concept that the social harmfulness of such an act is negligible. ${ }^{23}$ Assuming that the property of the Treasury is the sole legal asset subject to protection of article $69, \S 2$ of the PFC, the first of the aforementioned views should be supported. Nonetheless, the provision in question should be amended. It should not be reduced solely to a question of tax assessment and the possible reduction of the amount of tax due. It performs a function related to the correctness of the customs and fiscal control, and not to the issue of the amount of tax liability. The application of the Excise Duty Act and the regulations issued on its basis, as well as the regulations issued on the basis of the Act on National Treasury Administration, give rise to many obligations related to the transfer of data on the type, quantity or quality of excise goods. The crime under article $69, \S 2$ of the PFC refers to manufactured excise goods, thus the act cannot

\footnotetext{
${ }^{22}$ Wilk, Komentarz do art. 69 Kodeksu karnego skarbowego (2018a), article 69.

${ }^{23}$ Konarska-Wrzosek et al. (2013), p. 280.
} 
refer to situations related to processing, transport, storage, or destruction of excise goods. The crime in question therefore sanctions the provision of false data only at the stage of the manufacture of excise goods.

The generalised approach expressed in the provision of article $69, \S 3$ of the PFC refers to the ordinance of the Minister of Finance of 10th May, 2017, on customs and fiscal control of certain excise goods. ${ }^{24}$ Tobacco products are covered by the material scope of that regulation $(\S 1$, paragraph 1 , point $1 \mathrm{~b}$, third indent of that regulation). The provision is a consequence of the fact that the activity connected with production, import, or trade in tobacco products, and their marking requires conducting in a tax warehouse, and is subject to, customs and fiscal control. Therefore, the regulation is intended to ensure the correctness of the marking of excise goods, and control of their storage, processing, destruction and transport. All these issues are addressed by the ordinance. However, the causative act concerns only the removal of excise goods from the locations specified in the ordinance, and not a number of other obligations related to customs and fiscal control of excise goods.

The excise duty suspension procedure is one of the basic institutions of tax law, important for the marketing of goods. Its significance has been explained earlier. The provision of article $69 \mathrm{a}, \S 1$ of the PFC states that whoever, contrary to the provisions of the act, violates the conditions for applying the excise duty suspension procedure, produces, stores or trans-ships excise goods outside a tax warehouse shall be subject to a fine of up to 720 daily rates or deprivation of liberty for up to 2 years, or both of these penalties jointly. In cases of lesser weight, the perpetrator of the prohibited act specified in $\S 1$ shall be subject to the penalty of a fine for a fiscal offence. With regard to this provision, it is pointed out that it erroneously uses the clauses "contrary to the provisions of the law", "in breach of the conditions for the application of the excise duty suspension arrangement" ${ }^{25}$ It is enough to leave the second one. Currently, the suspended excise duty procedure is not applied to products manufactured outside a tax warehouse. This applies to all products.

In this part of the study it is worth noting that the construction of the provision of article 69a of the PFC is not correct and it is worth considering legislative changes to this element. All the elements expressed in the verbs used in the act: "produces", "stores", "trans-ships" are covered by the clause "in breach of the conditions for the application of the excise duty suspension arrangement". If such a procedure applies, performing the aforementioned activities outside a tax warehouse is contrary to the provisions of the Excise Duty Act (see article 47 of the Excise Duty Act). It seems that the legislator's intention was to limit the punishability of a violation of the suspension of excise duty procedure to the strictly defined behaviours referred to in article $69 \mathrm{a}, \S 1$ of the PFC. However, it is worth considering both the form of this provision and the possible extension of criminalisation related to infringements within the scope of the excise duty suspension procedure. It is important not only

\footnotetext{
${ }^{24}$ Journal of Laws of 2020, item 262.

${ }^{25}$ Łabuda (2017), p. 750.
} 
from the point of view of the fiscal obligations of taxable persons, but also from the point of view of control of tobacco products since the excise duty suspension procedure is connected with numerous information obligations of the entity applying it. Within the meaning of article 8, paragraph 1, point 1 of the Excise Duty Act, production is subject to excise duty. In the case of tobacco products, the act provides a legal definition of tobacco production. In accordance with article 99, paragraph 1 of the Excise Duty Act, the production of tobacco products within the meaning of the act is the manufacture, processing and packaging of tobacco products. In addition, the production of cigarettes is also the manufacturing of cigarettes, including by the consumer, using machinery for the manufacture of cigarettes (article 99, paragraph 1a of the Excise Duty Act). The production of cigarettes by a consumer by hand at home shall not be considered as the manufacture of cigarettes. It seems that such a definition should be transferred to the Penal Fiscal Code, although it should be noted that the issue of the definition of cigarette production-its very broad scope-raises doubts in the doctrine of tax law. ${ }^{26}$ The jurisprudence of administrative courts has a broad interpretation. ${ }^{27}$ This is how the legislative changes made in the Excise Duty Act are understood (the addition of the cited article 99, paragraph 1a and $1 \mathrm{~b}$ of the Excise Duty Act), i.e. the intention of the legislator to give the concept of "manufacture of cigarettes" the broadest possible scope.

The provisions of article $69 \mathrm{~b}$ and $69 \mathrm{c}$ of the PFC reveal the problem of the proper process of law making, which has recently been particularly intense in Poland. This is because there are legitimate doubts as to the procedure for their adoption (they were introduced within the framework of amendments at the final stage of legislative work, without going through the prescribed procedure for adopting the provisions). Moreover, it is incorrect that both in the explanatory memorandum and in the doctrine that these provisions are viewed only through the prism of value added tax and the specific practice of crime on the fuel market. ${ }^{28}$ There may be an impression that this is the scope of the regulation of these provisions. Such an impression arises from the fact that these regulations were developed within the framework of amendments to tax acts (the VAT Act and the Excise Duty Act) in order to solve specific problems occurring in practice in the application of taxes and combating large-scale fraud. This view is erroneous because the legislation in question applies to all excise goods in the context of intra-Community acquisition or supply. It should be noted at this point that there are reservations as to whether the act under article $69 \mathrm{~b}, \S 1$ of the PFC complies with all the directives resulting from the principle of legality of an act under criminal law. There are many obligations arising from intra-Community acquisitions or intra-Community supplies. It seems that article $69 \mathrm{~b}, \S 1$ of the PFC concerns tax obligations related to the determination and performance of a tax obligation.

\footnotetext{
${ }^{26}$ Zimny (2017), pp. 775-776.

${ }^{27}$ Judgement of the Voivodship Administrative Court of 21st July, 2016, case ref. No. WSA Kr I SA/KR 336/16, LEX No. 2120499.

${ }^{28}$ Łabuda (2017), pp. 754-756.
} 
In accordance with article $69 \mathrm{~b}, \S 1$ of the PFC, anyone who, contrary to the provisions of the act, makes an intra-Community supply or intra-Community acquisition of excise goods is subject to a fine of up to 720 daily rates or a penalty of imprisonment, or both. $\S 2$ of the same provision provides for a fiscal offence punishable by a fine. It consists of the implementation of the elements of article $69, \S 1$ of the PFC, with the proviso that the perpetrator's act meets the conditions of a case of lessor significance. The relationship between the provisions of article $69 \mathrm{a}, \S$ 1 of the PFC and article 54, 11 of the PFC, article 56, $\S 1$ of the PFC and article $76, \S$ 1 of the PFC is puzzling. Making an intra-Community supply or acquisition gives rise to certain obligations in the field of value added tax and excise duty. IntraCommunity acquisition is directly listed as an activity subject to excise duty (article 8, paragraph 1, point 4 of the Excise Duty Act). Intra-Community acquisitions also give rise to VAT obligations. It is therefore the case that article $69 \mathrm{a}, \S 1$ of the PFC in fact shifts the field of criminalisation-in relation to article 54, $\S 1$ of the PFC, article $56, \S 1$ of the PFC, article $76, \S 1$ of the PFC - to an earlier stage. The question is only whether procedural authorities are already in a position to effectively implement this provision at this stage. The fact is that the mechanisms referred to in article $69 \mathrm{a}, \S 1$ of the PFC are very often used by perpetrators who intend to avoid taxation, on the other hand their control at this stage (making an intra-Community acquisition, intra-Community supply) is difficult. It is established that such activities are performed in practice at a later stage, at which evasion should be considered (article $54, \S 1$ of the PFC, article 56, $\S 1$ of the PFC-tax evasion, article 76, $\S 1$ of the $\mathrm{PFC}$ - extortion of undue tax refund).

In accordance with article $69 \mathrm{c}, \S 1$ of the PFC, a person who, in breach of his or her obligation, moves excise goods from the territory of one Member State to the territory of another Member State through the territory of the country without a simplified accompanying document, or a commercial document replacing a simplified accompanying document, or without printing an e-AD with an assigned reference number, or another commercial document containing an e-AD reference number in the System, or a document replacing an e-AD, or, on the basis of these documents containing data inconsistent with the actual state of affairs, is subject to a fine of up to 720 daily rates, or a penalty of imprisonment, or both. As stated in $\S 2$ of the same article, in the case of a minor offence, the perpetrator of the offence referred to in $\S 1$ shall be liable to a fine for a fiscal offence. Movement of excise goods is a frequent activity associated with the production and marketing of tobacco products. In relation to article $69 \mathrm{c}, \S 1$ of the PFC, it concerns only such a movement of excise goods that is connected with the need to hold a specific document used in this type of activity. Article 2, paragraph 1, point 15 of the Excise Duty Act defines the "e-AD" as an electronic administrative document on the basis of which excise goods are moved under the excise duty suspension procedure. It should be pointed out here that the excise duty suspension procedure applies in the situation described in article 69c, $\S 1$ of the PFC because, according to article 40, paragraph 2 of the Excise Duty Act, the procedure applies if excise goods are moved from a tax warehouse on the territory of a Member State through the territory of the country to a customs authority in the territory of another Member State which supervises the actual removal of the 
goods from the territory of the European Union (point 5 of the same), through the territory of the country between tax warehouses in the territory of Member States (point 8 of the same); through the territory of a country from a tax warehouse to the territory of a Member State to a purchase in the territory of a Member State which is an entity authorised by the applicable tax authorities of this European Union Member State to receive excise goods under the excise duty suspension procedure or to entities covered by the exemption from excise duty resulting from article 31, paragraph 1 of the Excise Duty Act (point 9 of the same). Pursuant to article 2, paragraph 1, point 15a of the Excise Duty Act, a document replacing e-AD is a document on the basis of which excise goods are moved under the excise duty suspension procedure when the EMCS System is unavailable, containing the same data as e-AD. According to article 2, paragraph 1, point 16 of the Excise Duty Act, a simplified accompanying document is a document on the basis of which excise goods listed in Annex 2 to the Excise Duty Act, which are outside the excise duty suspension procedure, and ethyl alcohol fully denatured with substances permitted to denature ethyl alcohol under Commission Regulation (EC) No 3199/93 of 22 November 1993 on the mutual recognition of procedures for the complete denaturing of ethyl alcohol for the purposes of exemption from excise duty, are moved within the framework of an intra-Community supply or acquisition. ${ }^{29}$ The movement of excise goods is subject to customs and fiscal control. In principle, every movement of excise goods requires the completion of procedures defined by tax law and the possession of appropriate transport documentation. Failure to do so will result in criminal liability.

Under article $69 \mathrm{c}, \S 1$ of the PFC, the issue of an entity bearing criminal liability is problematic. It is pointed out that the crime is of an individual nature and may be committed by a person, on whom the obligation rests. ${ }^{30}$ A situation in which the transport organizer, the person ordering the transport, does not bear liability under article $69 \mathrm{c}, \S 1$ of the PFC should be considered as an error. Transports of goods are commissioned to shipping companies, so there is doubt as to whether the construction of a penal fiscal provision, which leads to punishment of drivers of vehicles transporting excise goods, is correct, particularly as there is no obligation resting on the party accepting the transport order, or the driver to verify the goods in transport and the formal requirements to be met by its transport. At the same time, there is no liability for ordering such transport without fulfilling the conditions stipulated by law.

The acts referred to in article 70-72 and article 75 of the PFC constitute fiscal crimes and offences related to the use of excise tax markings. Excise duty markings have already been discussed. The provisions of the Excise Duty Act formulate a number of obligations and prohibitions concerning excise duty markings. Generally speaking, it should be pointed out that free circulation of excise markings is not

\footnotetext{
${ }^{29}$ OJ EC L 288 of 23/11/1993, p. 12, as amended, EU OJ Polish Special Edition, chapter 9, vol. 1 , p. 249, as amended.

${ }^{30}$ Łabuda (2017), p. 762.
} 
allowed (see article 130, paragraph 1 of the Excise Duty Act), they must be recorded, stored, and transported in a prescribed manner (article 131 of the Excise Duty Act), there is an obligation to settle the excise markings transferred (articles 132 and 135 of the Excise Duty Act), and procedures are provided for in case of loss, damage or destruction of excise markings (article 138 of the Excise Duty Act). The provisions of the Penal Fiscal Code in the provisions of the paragraph referred to in the introduction secure some of these obligations taking into account the functions performed by excise tax markings (legalization, protection, and a fiscal function ${ }^{31}$ ). Thus, article 70, $\S 1$ of the PFC stipulates that whoever, contrary to the provisions of the act, sells or otherwise transfers excise tax markings to an unauthorised party shall be subject to the penalty of a fine of up to 720 daily rates or the penalty of deprivation of liberty for up to 2 years, or both of these penalties jointly. Criminal liability will also be borne by the purchaser of such markings, because according to article $70, \S$ 2 of the PFC, the penalty specified in article $70, \S 1$ of the PFC is subject to whoever purchases or otherwise accepts excise tax markings from an unauthorized party in order to use or put them into circulation. In addition, the person who removes them from the excise goods in order to reuse or circulate them will also be liable. The attempt to commit the aforementioned crimes is punishable. Pursuant to article $70, \S$ 4 , the penalty specified in $\S 1$ shall also be imposed on a person who, without being authorised to do so, possesses, stores, transports, sends or transfers excise duty markings. The provision of article $70, \S 5$ of the PFC introduces liability for misconduct in relation to the behaviour described in article 70, $\S 1,2$, and 4 of the PFC if it constitutes a case of lesser significance. Article 71 of the PFC stipulates that whoever, by a gross violation of the regulations on transport or storage of excise tax markings, exposes them to direct danger of theft, destruction, damage or loss, shall be subject to a fine of up to 480 daily rates. Another article concerns non-accounting for excise tax markings. Pursuant to article 72 of the PFC, anyone who, in breach of the obligation, fails to account on time with the competent authority for the usage of excise tax markings, in particular does not return unused, damaged, destroyed or invalid markings, is subject to a fine of up to 360 daily rates. Moreover, pursuant to article 75 of the PFC, an importer, an entity making an intra-Community acquisition and a tax representative who does not fulfil the obligation to obtain from an entity established outside the territory of the country for the settlement of the excise duty markings transferred to it is subject to a fine of up to 180 daily rates.

There are cases in which certain excise goods or excise goods under certain conditions or status are exempted from the obligation to mark them with excise tax markings. Of course, such an exemption must be clearly indicated by law. This is done in article 118 of the Excise Duty Act. Moreover, article 119 of the Excise Duty Act constitutes a statutory delegation for the minister in charge of public finances to grant an exemption - by way of a regulation - from the obligation to mark certain excise goods with excise duty markings if: (1) this is justified by an important interest of the state or entities obliged to mark excise goods with excise duty

\footnotetext{
${ }^{31}$ On the functions of excise tax markings, see more broadly: (Zimny 2017), pp. 824-825.
} 
markings; (2) it results from the provisions of European Union law or international agreements; (3) it indicates that certain excise goods are intended for use in the form of samples for scientific, laboratory or quality research. Cigars and cigarillos are covered by such exemption until 31st December, 2020, pursuant to $\S 2$ of the ordinance of the Minister of Finance of 20th August, 2010, on exemptions of excise goods from the obligation to mark them with excise markings. ${ }^{32}$ In addition, excise goods produced outside the national territory and intended for use at exhibitions, fairs, exhibitions and similar events may benefit from an exemption under the conditions laid down in the ordinance. Article 73 of the PFC provides for liability for acts related to the existence of exemptions from marking excise goods with excise markings. Pursuant to article $73, \S 1$ of the PFC, anyone who, in the use of an excise product, changes the purpose for which it is intended or fails to observe another condition, on the basis of which the exemption from the obligation to mark excise duty with excise markings on excise goods is subject to a fine of up to 720 daily rates. The provision of article $73, \S 2$ of the PFC introduces liability for a fiscal offence if the uncollected excise duty does not exceed the statutory threshold. It is doubtful whether the perpetrator can be held liable for the above act in the case of the exemptions provided for in the ordinance cited above. The provision of article $73, \S 1$ of the PFC clearly indicates that the objectives and conditions for exemption from excise duty on excise goods must be provided for by law.

\subsubsection{Customs Offences}

The crime of smuggling is stipulated in article 86 of the PFC. Paragraph 1 of this states that anyone who, in breach of his customs obligation, imports or exports goods abroad without presenting them to customs or without a customs declaration, thereby rendering the customs debt liable to depletion, shall be liable to a fine of up to 720 daily rates or deprivation of liberty, or both. Paragraph 2 stipulates that the same penalty shall be imposed on a perpetrator if the customs smuggling relates to goods traded with foreign countries subject to non-tariff regulation. $\S 3$ provides for the type of privileged offence described in $\S 1$ and 2 , which consists of the fact that the amount of customs duty exposed to depletion or value of goods traded with foreign countries subject to non-tariff regulation is of low value. In this case, the offender is only liable to a fine of up to 720 daily rates. An offence under article $86, \S 1$ and 2 of the PFC shall be a situation where the amount of customs duty at risk of depletion or the value of goods in foreign trade, which is subject to non-tariff regulation, does not exceed the statutory threshold.

That provision is referred to as customs smuggling because it is described as consisting of the failure of the person concerned to fulfil a customs obligation. This obligation is related to the import or export of goods from a third country to an EU Member State. These obligations are twofold. They are defined in the EU Customs

\footnotetext{
${ }^{32}$ Journal of Laws of 2019, item 2427, as amended.
} 
Code (hereinafter: UCC) ${ }^{33}$ The presentation of goods to customs bodies means notification of the customs authorities of the arrival of goods at a customs office or at any other place designated or approved by the customs authorities and of the availability of these goods for customs controls (article 5, point 33 of the UCC). However, a customs declaration shall be the act whereby a person indicates in the prescribed form and manner his intention to place goods under a given customs procedure, specifying, where appropriate, any particular arrangements to be applied. At present, such notifications are made in electronic form (article 6, paragraph 1 of the $\mathrm{UCC}^{34}$ ). These two obligations, taken as an alternative because it is the customs rules that determine when it is sufficient to present the goods to customs and when the customs declaration has to be made, remain essential for the recognition of the liability of the offender. However, it cannot be equated with the creation of a customs debt. It is true that such a procedure will most often arise in the event of failure to fulfil the obligations under article $86, \S 1$ of the CC (in particular in the case of the import and export of goods discussed in this study). However, not every failure to fulfil the obligation to present the goods or its customs declaration to the customs authority gives rise to a customs debt within the meaning of article 5, point 18 of the UCC. The existence of a customs duty which the perpetrator exposes to depletion (apart from failing to fulfil his obligations) is a necessary condition for attributing a crime to the offender under article $86, \S 1$ of the PFC. This provision is another example of a regulation which requires in contrecto determination of the obligations incumbent on the offender, their scope, whether there is in fact a customs debt, and thus the recourse to customs legislation, and the proper assessment of those standards.

The European Union is a customs union. This means that the exchange of goods throughout the territory between Member States may not be subject to import and export duties or other equivalent charges. However, there are different rules and restrictions on tobacco products. Limits are set at Union level (800 cigarettes, 400 cigarillos, 200 cigars, $1 \mathrm{~kg}$ of tobacco). States may provide for higher thresholds than those set, which is also the case. Exceeding such limits in the movement of goods between EU countries will not, however, constitute a crime under article 86, § 1 of the PFC. The position is correct that as of the date of Poland's accession to the European Union, the acts which depenalysed the characteristics of the crimes specified in articles 85-96 of the Code of the PFC in relation to trade in goods with countries belonging to the European Union were depenalyzed. ${ }^{35}$ Violation of tax obligations related to exceeding the above limits should therefore be sought in

\footnotetext{
${ }^{33}$ Regulation (EU) No. 952/2013 of the European Parliament and of the Council of 9th October, 2013, laying down the Union Customs Code, EU OJ L 269, hereinafter referred to as "UCC".

${ }^{34}$ The detailed terms and conditions are specified in the ordinance of the Minister of Finance of 8th September, 2016, on customs declarations, Journal of Laws of 2018, item 2262.

${ }^{35}$ Decision of the Supreme Court of 22nd November, 2006, case ref. No. V KK 247/06, LEX No. 202287.
} 
completely different fiscal norms (the acts referred to in Chapter 6 on excise duty should be considered here).

The fundamental principle of the EU is a common customs tariff in its relations with third countries. The Union's Customs Code, as mentioned above, is a key Union act in this area. To a certain extent, it is complemented by EU regulations and national legislation. The import or export of goods must be identified with this act within the customs union (EU), which in turn gives rise to a customs obligation and failure to comply with it leads to the fulfilment of the constituent element of the crime in question. International agreements, domestic laws and regulations may contain exemptions from the principle that every carriage or export gives rise to a customs obligation. Such exceptions, of course, apply. The crime of customs smuggling is one of the most frequently committed customs crimes. At present, tobacco products are not subject to non-tariff regulation. Therefore, this concept will not be discussed in this study. The crime of customs smuggling may be cumulative in relation to other crimes under the Penal Fiscal Code. The collection of customs duty is not the only receivable that can be linked to the import or export of a product. Smuggling itself may also be related to the failure to fulfil other obligations and be subject to criminal liability or to the depletion or exposure to depletion of tax other than excise duty, e.g. value added tax. In jurisprudence the opinion has been expressed that the object of a fiscal tort under article 86, $\S 1$ of the PFC may be goods legally purchased abroad, not by way of crime, because the perpetrator of a crime cannot be subject to the obligation of self-denunciation. Moreover, it was also indicated that only the goods for which Poland is a destination country may be the subject of this act. ${ }^{36}$ Commentators discussing this provision cite the decision of the Court of Appeal in Poznań, ${ }^{37}$ in which it did not justify the thesis presented. A wider commentary is also lacking in studies referring to this judicature. However, the thesis of this ruling is not justified. First of all, it should be noted that Poland was not a member of the European Union at the time of committing the offence and the decision of the Court of First Instance in the aforementioned judgement. There are no grounds whatsoever for assuming that it may only relate to goods for which Poland is a destination country, mainly due to the fact that currently the territory of Poland is in the area of the customs union. The entire area of the European Union is therefore protected, so that there are no illegal imports or exports from the European Union. It does not matter what their destination country is. From the point of view of proceedings for acts under article $86, \S 1$ of the PFC, it is more important to make determinations regarding the origin of goods. For example, if the goods are not stopped at the border (the EU's external border), then liability under the aforementioned article will only be possible if it is shown that the goods originate from a non-EU country. The same will apply to exports. Another controversial thesis is that the perpetrator cannot be held criminally liable in the case of goods of illegal origin

\footnotetext{
${ }^{36}$ Judgement of the Court of Appeal in Poznan of 6th November, 2000, Case No. II Aka 430/00, Legalis No. 54145.

${ }^{37}$ Wilk, Komentarz do art. 86 Kodeksu karnego skarbowego (2018b), article 86, thesis 5 .
} 
being the subject of smuggling. We have already analysed the problem of differentiation in the taxation of goods of legal and illegal origin. It seems that the theses presented in this respect in the earlier part of the study should also refer to the crime of customs smuggling discussed here. To sum up, the object of a customs offence under article 86, § 1 of the PFC may be goods of illegal origin, as well as goods whose destination is a country other than Poland.

Article 87 of the PFC stipulates a crime known as customs fraud. In this case, the entity fulfils the obligations resulting from article $86, \S$ of the PFC and relevant customs regulations, but at the same time misleads the authority authorised to conduct customs control. The offender undertakes this action in order to avoid payment of the customs duties. A crime can therefore be committed intentionally only with direct intent. ${ }^{38}$ The perpetrator's action consists in causing the customs authority to make an assessment, inconsistent with the objective state of affairs, of the relevant circumstances constituting the tax (duty) assessment, which, for example, may relate to any calculation prerequisites related to the application of the relevant customs tariff. ${ }^{39}$ In relation to this crime, it is noted in the literature that this crime may be committed exclusively through an action (contrary to the crime of fraud under article 286, $\S 1$ of the PFC). ${ }^{40}$ Accordingly, the offender shall not be liable to prosecution if the customs authority erred in fact or in law and the person subject to the procedure makes use of it. The authorities authorised to conduct customs inspections are the authorities of the National Treasury Administration. In actual fact, this will be an officer authorised to carry out inspections. It should be emphasised that an officer must be misled, i.e. the mere provision of erroneous data by the perpetrator is not sufficient, as a necessary condition is that a specific officer who performs the inspection has an erroneous idea of the factual or legal situation in his/her awareness. If a public officer, despite defective data, is not misled, the offence under article 87, $\S 1$ of the PFC will not be in the form of an act of execution. In such a case, the liability for attempting to act pursuant to article $87, \S 1$ of the PFC should be considered.

Pursuant to article $87, \S 1$ of the PFC, whosoever, by misleading the authority authorised to conduct customs inspections, exposes the customs receivable to depletion is subject to a fine of up to 720 daily rates or deprivation of liberty, or both. Article $87, \S 2$ of the PFC refers to the same executive activity with respect to goods or services in foreign trade, which are subject to non-tariff regulation. The criminal liability is the same as in $\S 1$. The provision of article $87, \S 3$ of the PFC is a privileged type of crime under article $87, \S 1$ or 2 . The perpetrator is liable to a fine of up to 720 daily rates if the amount of customs duty liable to depletion or value of goods or services in foreign trade, which are subject to non-tariff regulation, is of low value. However, the provision of article $87, \S 4$ of the PFC introduces liability for an

\footnotetext{
${ }^{38}$ Otherwise: (Prusak and Skowronek 2018), p. 154.

${ }^{39}$ Decision of the Supreme Court of 28th January, 2005, case ref. No. V KK 377/04, LEX No. 146256.

${ }^{40}$ Magnuszewska (2016), p. 71.
} 
offence if the amount of customs duty liable to depletion or value of goods or services in foreign trade, which are subject to non-tariff regulation, does not exceed the statutory threshold.

A crime similar to the act under article $87, \S 1$ of the $\mathrm{CC}$ is the act stipulated in article 92 of the PFC, and occasionally this latter act is termed customs fraud. It consists of defrauding the repayment of a customs debt or the remission of a customs debt. Pursuant to article 92, $\S 1$ of the PFC: whosoever, by providing data inconsistent with the actual state of affairs or by concealing the actual state of affairs, misleads the competent authority by exposing it to the risk of undue repayment of the customs debt or remission of the customs debt due to be paid, is subject to a fine of up to 720 daily rates or deprivation of liberty, or both. The privileged type of this offence is provided for in $\S 2$, which indicates that the perpetrator is subject to a fine of up to 720 daily rates if the amount exposed to undue repayment or remission of customs duty is of low value. However, if this amount does not exceed the statutory threshold, the perpetrator of the prohibited act is liable to a fine for a fiscal offence. The EU Customs Code lays down the rules for the repayment or remission of customs duties (see article 116-118 of the UCC). The point is, of course, that the sums unduly and unlawfully collected are to be refunded. However, this does not apply to conscious action. Repayment or remission shall be made upon request. In most cases, the moment of its submission should be tied to the implementation of the prerequisites by the perpetrator. Misrepresentation should be understood as specified in the aforementioned article $87, \S 1$ of the PFC. The crime under article $92, \S 1$ of the PFC includes another form of causal action-concealment of the actual state of affairs, i.e. concealment, the conscious omission of the essential elements for performing repayment or remission. The repayment or remission of the customs debt is not required for committing this crime.

The provision of article $90, \S 1$ of the PFC criminalises the removal of goods or means of transport from customs supervision. This crime is punishable by a fine of up to 720 daily rates, or by imprisonment for up to 3 years, or both. Pursuant to article $90, \S 2$ of the PFC, the same penalty is imposed on anyone who destroys, damages or removes a customs seal without the consent of an authorised authority. In cases of lesser significance, the perpetrator of the prohibited act specified in $\S 1$ or 2 shall be subject to the penalty of a fine for a fiscal offence. Customs supervision means action taken by the customs authorities to ensure that customs legislation and, where appropriate, other provisions applicable to goods subject to such action are observed (article 5, point 32 of the UCC). In the case of an offence under article 90, $\S$ 2 of the PFC, the principles arising from article 134 of the UCC are applicable. Firstly, goods are subject to customs supervision from the moment they enter the customs territory of the Union. Secondly, goods must remain under customs supervision for as long as necessary to determine their customs status and are not taken up without the approval of the customs authorities. The means of transport referred to in article $90, \S 1$ of the PFC is defined in article 53, $\S 18$ of the PFC as an object for the transport of persons or goods, in particular a road vehicle, rail transport, a trailer, a semi-trailer, a vessel or an aircraft. The concept of "customs seal" is an example of a situation where the legislator fails to ensure the coherence of the system. The issue of 
incorrectly used wording may be removed pursuant to article 53, § 32 of the PFC. This provision introduces the rule that the meaning of certain terms should be determined in accordance with the meaning given to them in specific tax acts, and the determination of the law actually referred to by the legislator allows the adoption of an appropriate term and its meaning. However, we should postulate that the legislator should properly and precisely define the characteristics of a prohibited act. In customs law and proceedings there is no "customs seal" but an "official seal" (article 65 of the law on the NTA). The regulations specify the conditions under which an official seal may take place; this is not required and applied in all cases. In principle, the authorities of the National Treasury Administration (the head of the customs and tax office or a person authorised by him/her) have the power to remove official seals. The terms removes, destroys and damages were discussed in an earlier part of this study. The provision of article 94 of the PFC is related to customs supervision. Failure to provide oral or written explanations relevant to customs controls or failure to provide access to the required documents concerning foreign trade in goods or services shall be criminally liable. The penalty for this fiscal crime is a fine of up to 720 daily rates $(\S 1)$. According to $\S 2$, a person who in some other manner frustrates or hinders a person authorised to conduct customs inspections or supervision activities shall be liable to the penalty, in particular, whosoever refuses to carry out preparatory acts for a customs inspection without complying with the obligation to deliver the goods immediately to the place designated by the customs authority. In cases of lesser significance, the perpetrator of the above acts shall be subject to a penalty for a fiscal offence. The construction of article 94 of the PFC could be simpler, even if one wanted to calculate examples of behaviour that would hamper the performance of customs control activities. It is precisely only customs inspection that should be included in the constituent elements of this crime. The use of the expression "customs supervision" makes the act described in article 94, $\S 1$ of the PFC of an indefinite nature and thus violates the basic principles of criminal law (the principle of determination of a prohibited act). The source of the obligation, the non-fulfilment of which is subject to criminal liability, can be found in article 72 of the NTA Act. The scope is very extensive. In criminal law (under the Criminal Code), the term "prevent" has long been understood not only as a complete impossibility of any action, but also as a hindrance to it. The wording of article 94, § 2 of the PFC would suggest a slightly different meaning.

Another provision of article 91 of the PFC typifies customs goods handling. Pursuant to article $91, \S 1$ of the PFC, whosoever purchases, stores, transports, moves or transfers goods being the subject of a prohibited act specified in article $86-90, \S 1$ of the PFC or assists in its sale or accepts or assists in its concealment, shall be subject to a fine of up to 720 daily rates or deprivation of liberty for up to 3 years, or both of these penalties jointly. This is an intentional crime. The aforementioned provision refers to article 86 of the PFC (customs smuggling), article 87 of the PFC (customs fraud), article 88 of the PFC (violation of the temporary admission procedure), article 89 of the PFC (violation of the conditions for customs exemption), and article $90, \S 1$ of the PFC (removal of goods or means of transport from customs supervision). Some of these provisions have been discussed. The 
others are not even potentially applicable to the problem of illegal smuggling. The crime of customs goods handling will relate to goods originating from strictly defined criminal offences. It is therefore necessary to establish evidence as to the origin of the goods. ${ }^{41}$ The provision of article $91, \S 2$ of the PFC deals with inadvertent customs goods handling. It is committed by someone who purchases, stores, transports, sends or moves goods which, on the basis of accompanying circumstances, should and can be assumed to be the subject of a prohibited act specified in article 86-90, $\S 1$ of the PFC, or assists in its sale, or accepts the product or assists in its concealment. The perpetrator of this act is liable to a fine of up to 720 daily rates. In the provision of article $91, \S 3$ of the PFC, the legislator provided for a privileged type of act under article $91, \S 1$ of the PFC. The perpetrator is liable to a fine of up to 720 daily rates if the amount of customs duty or the value of goods in foreign trade, which is subject to non-tariff regulation, is of low value. If this value does not exceed the statutory threshold, the perpetrator of the prohibited act specified in $\S 1$ or 2 is liable for a fiscal offence (article $91, \S 4$ of the PFC). The elements of article $91, \S 1$ and $\S 2$ of the PFC defining a causal activity are presented alternatively. It is obvious that for the existence of a crime it is sufficient to realize one of these verbal characteristics. These terms should be given the same meaning as they are commonly understood. We are not going to discuss here each of the wordings used in this provision.

The provision of article 93, $\S 2$ of the PFC concerns the proper functioning of a customs free zone or a customs warehouse. ${ }^{42}$ According to it, anyone who grossly violates the customs legislation on the conditions of operation of a customs free zone or a customs warehouse is liable to a fine of up to 240 daily rates. Pursuant to article 93, $\S 3$ of the PFC, the penalty specified in $\S 2$ shall also be imposed on any person who grossly violates the provisions on the conditions of temporary storage. The creation and operation of a customs free zone are defined in the Union Customs Code. The Member States are authorised to designate customs free zones (article 243 of the UCC). Examples of behaviours that may constitute an act under article 93, $\S 2$ of the PFC are violations of the rules related to the functioning of such an area, e.g. the introduction or removal of goods from it (see article 243-249 of the UCC), its control, notification to customs authorities, performance of commercial, industrial and service activities contrary to the provisions of customs law. The Union Customs Code also defines a customs warehouse as referred to in article 93, § 3 of the PFC. The customs warehousing procedure allows non-Union goods to be stored in places approved by the customs authorities for this procedure and under customs supervision. The provisions of the Union Customs Code lay down the rules for the operation of such a warehouse and there is a risk of criminal liability for violation of them. In both offences, the legislator used the term "grossly". The term is generalised

\footnotetext{
${ }^{41}$ Judgement of the Court of Appeal in Szczecin of 25th February, 2016, Case No. II AKa 226/15, LEX No. 2025614.

${ }^{42}$ The provision of $\S 1$ was repealed in connection with Poland's accession to the EU.
} 
in nature and in practice may cause difficulties in determining which infringements are of such a nature, i.e. serious, unambiguous and glaring.

Pursuant to article $95, \S 1$ of the PFC, anyone who, contrary to the obligation, fails to keep documents relevant for customs control is subject to a fine of up to 180 daily rates. In accordance with article 92, $\S 2$ of the PFC, in cases of lesser significance, the perpetrator is liable as for a fiscal offence.

The closing regulations of chapters 6 and 7 of the PFC are analogous in content. The difference is limited solely to the scope of the legislation to which each of the following provisions applies. Pursuant to article $84, \S 1$ of the PFC, anyone who does not fulfil the obligation to supervise the observance of rules binding in the activity of an entrepreneur or other organisational unit, allows, even if unintentionally, a prohibited act specified in this chapter to be committed (this means chapter 6 , the acts referred to in articles $54-83$ of the PFC), is subject to a fine for a fiscal offence. Pursuant to article 84, $\S 2$ of the PFC, the provision of $\S$ 1 shall not apply if the act of the perpetrator satisfies the features of another fiscal offence or fiscal misdemeanour specified in this chapter or if the failure to fulfil the duty of supervision is a part of their characteristics. As has already been stated, the provision of article 96 of the PFC is constructed in the same way: $\S 1$ typifies the liability of a person who, without fulfilling the obligation to supervise the observance of the rules binding in the activity of a given entrepreneur or other organisational unit, allows, even if only unintentionally, a prohibited act specified in this chapter to be committed (this means chapter 7, the acts referred to in articles 85-95 of the PFC). In such a case, a fine for a fiscal offence shall be imposed. However, in accordance with $\S 2$ of the provision, $\S 1$ shall not apply if the act of the perpetrator satisfies the features of a different fiscal offence or fiscal misdemeanour specified in this chapter or if the failure to fulfil the duty of supervision belongs to their features. Both provisions (article 84 and 96 of the PFC) extend criminal liability (although it is only liability for an offence) to conduct that does not result from the violation of certain norms of tax law, but from the fact that the offence was committed by another person as a result of a lack of supervision over compliance with the rules applicable to the business of the entrepreneur or other organisational unit. It is a specific form of perpetration in the Penal Fiscal Code, outside the traditional forms of perpetration (article $9, \S 1$ and 2 of the PFC) and the principle resulting from article $9, \S 3$ of the PFC. It should be noted that failure to comply with supervision obligations must be intentional. However, inadvertence may include the commission of an offence as defined in chapter 6 or chapter 7 , as appropriate.

\subsection{The Illicit Manufacture of Tobacco Products}

The illicit production of tobacco products in Poland is another phenomenon, which must be tackled in order to eliminate the crime discussed in this study. The external border of the European Union is located in the territory of Poland. It is one of the longest. It is $1163 \mathrm{~km}$ long, of which $535 \mathrm{~km}$ is the border with Ukraine, $418 \mathrm{~km}$ 
with Belarus, and $210 \mathrm{~km}$ with Russia (Kaliningrad Oblast). The smuggling of cigarettes and other tobacco products across the external borders of the European Union is a major risk. It results from the strengthening of the border, active operations of the Border Guard service in combating all forms of illegal transport of goods, and equipping the border with advanced devices for detecting smuggling. The illicit production of cigarettes for distribution within the country and for transport to other Schengen countries reduces the risks mentioned above, while still remaining a lucrative activity for criminal groups. ${ }^{43}$

The act of 2nd March, 2001, on the manufacture of ethyl alcohol and the manufacture of tobacco products ${ }^{44}$ states in article 12a, paragraph 1, that whosoever, without the required entry in the registers referred to in article 3, paragraph 2, manufactures tobacco products shall be subject to a fine, restriction of liberty or deprivation of liberty for up to 1 year. Economic activity related to the manufacture of tobacco products is a regulated activity within the meaning of the act of 6th March, 2018, the Law on Entrepreneurs. ${ }^{45}$ This means that the production of tobacco products requires registration in the register of tobacco producers, which is preceded by an administrative procedure and the fulfilment of legal conditions. The next paragraph of article 12a provides for a qualified type consisting of permitting the act in question in respect of high-value tobacco products. High-value should be considered as a value exceeding 200,000 PLN (article 115, § 5 of the CC in conjunction with article 116 of the CC). In such a case, the penal sanction is slightly higher, the penalty of deprivation of liberty may be pronounced for up to 2 years, while the possibility of imposing a fine or penalty of restriction of liberty remains. Moreover, if the perpetrator has made the perpetration of the crimes in question a permanent source of income, then, pursuant to article 14 of the act on the production of ethyl alcohol and manufacture of tobacco products, the perpetrator shall be liable to incur higher criminal penalties, i.e. up to 3 years of imprisonment, while the legislator has not provided for other alternative penalties (fines, imprisonment). Article 14a of the act on the production of ethyl alcohol and manufacture of tobacco products provides for the possibility to order the forfeiture of items being the subject of crime or intended for its perpetration, even if it is not the property of the perpetrator. In article 14a of the aforementioned act, the legislator should use precise definitions and those adopted on the basis of the Criminal Code. This article uses the term "object of crime". It should be assumed that the article in question de facto concerns the forfeiture of an object derived directly from a criminal offence. It is not correct that under the act on the production of ethyl alcohol and production of tobacco products, the forfeiture of items originating from crime is optional, whereas in the Criminal Code the ruling on the same items is obligatory. Another inconsistency is that, in principle, article $44, \S 2$ of the Criminal Code, concerning the forfeiture of objects used or intended to be used for committing a crime, has been

\footnotetext{
${ }^{43}$ These issues are discussed in more detail in the criminological part of the study.

${ }^{44}$ Journal of Laws of 2018, item 2352.

${ }^{45}$ Journal of Laws of 2019, item 1292 as amended.
} 
repeated in article 14a of the act on the manufacture of ethyl alcohol and manufacture of tobacco products, which makes this measure optional. The regulation of article $14 \mathrm{a}$ of the aforementioned act would make sense only in such a way, if an obligatory forfeiture of objects used or intended for committing a crime was introduced. The provision of article 14 of the act on the production of ethyl alcohol and production of tobacco products is also unnecessary, as article 65 of the Criminal Code would be sufficient. The introduction of the aforementioned provisions concerning forfeiture and increasing criminal liability, took place in isolation from the provisions of the general part of the Criminal Code. The solutions adopted are irrational. If one assumes that a different regulation of a specific issue is already sufficient grounds to exclude the application of the provision of the general part of the Criminal Code pursuant to the provision of article 116 of the Criminal Code, ${ }^{46}$ then articles $12 \mathrm{a}$, $14,14 \mathrm{a}$ of the act on the manufacture of ethyl alcohol and tobacco products exclude the application of the provisions of the general part of the Criminal Code in such a way that: (1) a decision on the confiscation of objects directly originating from a crime is only optional, whereas in the Criminal Code it is always obligatory; (2) the penalty of imprisonment for a perpetrator who has made committing these crimes a permanent source of income for himself is more lenient than would be the case on the basis of article 65, $\S 1$ of the Criminal Code. Doubts may arise as to whether the provision of article $65, \S 2$ of the Criminal Code is to be applied. Although it should be pointed out that making article 14a stricter eliminates penalties not limiting freedom (a fine, or penalty of restriction of liberty), which is not done by article $65, \S 1$ of the Criminal Code. The ethyl alcohol and tobacco products act also raises the question of whether article 12a of the act applies to persons producing cigarettes and other tobacco products for their own use. The Supreme Court answered the question concerning the production of alcohol in the affirmative in the resolution of 30th November, 2004, case ref. No. I KZP 23/04. ${ }^{47}$ The construction of article 12a, paragraph 1 of the act on the manufacture of ethyl alcohol and the manufacture of tobacco products equates the manufacture of alcohol with the manufacture of tobacco products, so it could be argued that this position of the Supreme Court could also apply to the manufacture of cigarettes for personal use. Notwithstanding the fact that the above resolution should be critically analysed ${ }^{48}$ and consequently disagree with the Supreme Court, a number of inconsistent regulations should be considered with respect to the problem of cigarette or other tobacco products, including Polish tax regulations (the Excise Duty Act), EU regulations, and administrative provisions on tobacco production. Their comprehensive analysis, determining which of them is of decisive importance for determining the normative content of the characteristics of an act under article 12a, paragraph 1 of the act on the manufacture of ethyl alcohol and manufacture of tobacco products may only lead

\footnotetext{
${ }^{46}$ Raglewski, Stosunek przepisów części ogólnej nowego kodeksu karnego do innych ustaw przewidujących odpowiedzialność karną (1998), p. 27. Otherwise: (Wojciechowski 2002), p. 232.

${ }^{47}$ LEX No. 132570.

${ }^{48}$ See aptly: (Warylewski 2005), p. 139 et seq.
} 
to certain results. ${ }^{49}$ In this study there is no place for a detailed presentation of the issue raised. Only a conclusion will be presented. Currently, the manual production of tobacco products, in a home-made way, without the use of machines, remains fully legal. Such a person should not be held criminally liable under article 12a, paragraph 1 of the aforementioned act.

The provisions criminalising the illicit manufacture of tobacco products should be amended. First, a clear distinction needs to be made between the production of a significant quantity of tobacco products, production in order to obtain a financial, personal and marketing advantage, and the manufacture of products for personal use. Under the current legislation, not only does the problem of determining the scope of liability under article $12 \mathrm{a}$, paragraph 1 of the act on the manufacture of ethyl alcohol and manufacture of tobacco products, described above, arise, but above all, there is no clear increase in the penal sanction for behaviours involving large-scale illegal manufacture of tobacco products. Secondly, the forfeiture of objects used to commit a crime, i.e. machinery and equipment used for illegal tobacco production, should be subject to mandatory confiscation. Thirdly, the provision of article 14a of the act on the manufacture of ethyl alcohol and tobacco products should be deleted. As already mentioned, the provision of article 65 of the Criminal Code is sufficient. Moreover, it will remove any doubts as to which of these provisions should be applied in criminal cases under the act. In addition, the terminology used in criminal legislation in the ethyl alcohol and tobacco products act should be clarified. Fourthly, it is worth considering the introduction of criminal preparation for the crime of illicit manufacture of tobacco products. A further remark concerns the application of the criminal law provisions of the act on ethyl alcohol production and the manufacture of tobacco products. The interpretation of the constituent elements of individual offences should take into account tax regulations, in particular the Excise Duty Act and its definitions of tobacco products and the production of tobacco products.

\subsection{The Criminal Code}

As can be seen from the previous part of the study, the provisions of the Criminal Code, its general part will be applied in a very limited scope (resulting from article $20, \S 2$ of the PFC) to cases related to crime involving the illegal production and trade in tobacco products, decided on the basis of the Penal Fiscal Code. It will be slightly different in cases concerning the illegal production of tobacco products due to article 116 of the Criminal Code and the fact that this aspect is regulated by another act (the act on the manufacture of ethyl alcohol and tobacco products). Selected provisions of the general section of the Criminal Code were commented on in the part devoted to crimes under this act. No provision was selected from the

\footnotetext{
${ }^{49}$ See more on the scope of criminalisation under article 12, paragraph 1 of the act on the production of ethyl alcohol and tobacco products: (Zontek 2019), pp. 66-81.
} 
catalogue of articles of the Criminal Code referred to in article 20, $\S 2$ of the PFC, which would require a detailed presentation within the framework of this study because of its importance for combating crime related to the illicit trade in tobacco products. Therefore, it was confined solely to signalling that in practice, in cases concerning the discussed type of crime, the enumerated provisions of the Criminal Code will be applied.

It is obvious that criminal activity related to illicit trade in tobacco products may consist of the perpetrator's compliance with the prohibited acts provided for in the Criminal Code, the Penal Fiscal Code or the act on the manufacture of ethyl alcohol and tobacco products. This will be decided by specific factual arrangements and the nature of the perpetrators' activities. Therefore, as in the previous sections, the individual offences of the Criminal Code will not be discussed here, also due to the fact that they do not show such a direct connection with crime related to the illegal trade in tobacco products as the acts stipulated in the Penal Fiscal Code or the act on the production of ethyl alcohol and tobacco products.

However, two points will be noted. In the provision of article 258 of the Criminal Code, the Polish legislator, irrespective of the restriction of criminal liability resulting from article 65 of the Criminal Code, and article 37, 1 , point 2 and 5 of the PFC, criminalises participation in an organised criminal group. In accordance with article 258, $\S 1$ of the Criminal Code, whosoever participates in an organised group or association aiming at committing a crime or fiscal offence shall be subject to the penalty of deprivation of liberty for a term of between 3 months and 5 years. The qualified types of this offence are further specified. Thus, in $\S 2$, criminal liability will be more severe, with a penalty of imprisonment from 6 months to 8 years, if the criminal group or association referred to in article $258, \S 1$ of the Criminal Code are of an armed nature or are aimed at committing a crime of a terrorist nature. $\S 3$ provides for a higher sanction, i.e. from 1 year to 10 years, for anyone who establishes or manages a group or association referred to in article $258, \S 1$ or 2 of the Criminal Code. The latter type of qualification consists of setting up or directing a group or association with the aim of committing a terrorist offence. This act is punishable with imprisonment for 3 years or more. Therefore, regardless of the liability for other crimes committed or fiscal offences, the perpetrator will also be liable for their very participation in a criminal group (association), their establishment and management. Moreover, to incur liability under article 258 of the Criminal Code it is not necessary to commit another offence. The traits of this act are fulfilled when a person belongs to a criminal group, occupies a place in its structure, carries out orders, tasks, etc. Individuals belonging to criminal groups involved in the illicit trade in tobacco products should be held accountable for their involvement in such organisations. The provision of article 259 of the Criminal Code specifies the premises for not punishing a case for an offence under article 258 of the $\mathrm{CC}$. This will be the case if the offender who voluntarily withdrew from participation in a criminal group or association and disclosed to a law enforcement authority all the relevant circumstances of the act committed, or if the offender who voluntarily withdrew from participation in a criminal group or association and prevented the commission of the intended offence, including a fiscal offence. The purpose of this 
provision is to create instruments to combat organised crime and to encourage members of groups to break links with such an organisation. ${ }^{50}$ It is not the only institution of this type in Polish law. Since 1997, the so-called Minor Crown Witness Act has been in force. ${ }^{51}$ In the Criminal Code we also find the institutions of the so-called minor crown witness. The provision of article $60, \S 3$ of the Criminal Code states that the court applies an extraordinary leniency of the sentence, and may even conditionally suspend its execution in relation to the offender cooperating with other persons in committing the crime, if he discloses to an authority appointed to prosecute crimes information concerning the persons participating in committing the crime and important circumstances regarding its commission. Although these institutions are controversial, they are an essential instrument in the fight against organised crime. Remember that such groups are hermetic, operate in a very professional manner, and are difficult to detect. Obtaining a repentant offender by authorities can sometimes be the only way of prosecuting those involved in managing and setting up criminal groups, as well as recovering and confiscating money from them. The sense of the functioning of these institutions should not be called into question. They require further development and professionalization, in particular in such a way that the services are able to attract in a wider manner the members of criminal groups in their hierarchy. Furthermore, the evidence (frequently very extensive) obtained as a result of explanations/statements from a crown witness should be precisely recorded in the course of proceedings.

Studies and analyses carried out in the course of the project ${ }^{52}$ show that, despite the preliminary study on increasing the imperviousness of the European Union's external border and the trend towards relocating illegal factories to the Schengen area, criminal groups are still trying to smuggle goods across the border. ${ }^{53}$ As already indicated, this is due to the high profits from smuggling and, at the same time, the relatively low losses resulting from the detection of smuggling. Officers from the Police Central Investigation Bureau estimate that the loss resulting from the detection of illegal cigarette transport is compensated for by another-second or third successful smuggling. The organisers of such transports very often remain elusive because they do not undertake activities directly related to the preparation and implementation of the transports. In most cases, the driver is not aware that he or she is transporting illegal tobacco products. All the more so as the ways of hiding smuggled goods are many and often changed. The information obtained shows that criminal groups are interested in obtaining and corrupting officers of the Border Guard. Such cases are not common, but it is necessary to take action to monitor this phenomenon, conduct research into its occurrence and place great emphasis on its

\footnotetext{
${ }^{50}$ Flemming and Kutzmann (1999), p. 88.

${ }^{51}$ The Act of 25th June, 1997, on Crown Witnesses, Journal of Laws of 2016, item 1197.

${ }^{52}$ Based on discussions with representatives of state authorities responsible for prosecuting and combating crime related to illegal smuggling and production of tobacco products.

${ }^{53}$ See (Laskowska 2017); also: (Buczkowski, Cudzoziemcy jako sprawcy przestępstw gospodarczych - wyniki badań aktowych 2017).
} 
prevention. In this respect, the Polish Criminal Code provides for liability for the crime of passive bribery (article 228, $\S 1$ of the Criminal Code), i.e. acceptance of a material or personal benefit in connection with the performance of public functions; active bribery (article 229, $\S 1$ of the CC) consisting of granting or promising a material or personal benefit to a person performing a public function in connection with the performance of this function; and paid protection (article $230, \S 1$ of the CC, article $230 \mathrm{a}, \S 1$ of the $\mathrm{CC}$ ). In connection with corrupt practices, liability for abuse of power or failure to perform duties by a public official may also be applicable. Officers of the Border Guard and the National Treasury Administration are public officers and persons performing public functions within the meaning of the provisions of the Criminal Code.

\subsection{Sanctions}

\subsubsection{Penalties}

As results from the descriptions of particular crimes presented above in the Penal Fiscal Code, the penalty of a fine plays a crucial role. It may be pronounced for any of the aforementioned crimes, including in many cases imprisonment. Such a solution should be considered correct due to the financial nature of the crimes covered by the Penal Fiscal Code. A fine measured in daily rates is applicable to fiscal offences. Pursuant to article 23, $\S 1$ of the PFC, unless the Code provides otherwise, the lowest number of rates is 10 , the highest number is 720 . It is for the court to determine the number of daily rates for the fine and the amount of one daily rate for a fine. One daily rate depends on the minimum remuneration. It is established in an ordinance of the Council of Ministers. From 1st January, 2020, the minimum remuneration shall be $2,600.00$ zloty. ${ }^{54}$ The daily rate may not be lower than one thirtieth of the minimum remuneration ( 86.67 zloty) or exceed four hundred times its value (1,040,000 zloty). The maximum fine may therefore reach 748,800,000 zloty. When determining the daily rate, the court takes into account the offender's income, personal and family conditions, property relations and income opportunities (article 23, $\S 3$ of the PFC).

For offences, the fine is imposed in a different way. In the Polish legal system it has been assumed that this is done in terms of amounts (so there are no daily rates). The fine for a fiscal offence (article 48, $\S 1$ of the PFC), unless the Code provides for an exception, may range from one tenth of the minimum remuneration ( 260 zloty) to twenty times the minimum remuneration (52,000 zloty). Similarly as in the case of imposing a fine for a fiscal offence, and also determining the amount of the fine for

\footnotetext{
${ }^{54}$ The ordinance of the Council of Ministers of 10th September, 2019, on the minimum remuneration for work and the minimum hourly rate in 2020, Journal of Laws of 2019, item 1778.
} 
committing an offence, the court takes into account the financial and family relations of the perpetrator, his or her income and earning potential (article $48, \S 4$ of the PFC).

The construction of the fine under the Criminal Code is similar to that of the Penal Fiscal Code. For offences, fines are also imposed at daily rates, but the limits of the rates and their levels are different. Thus, the lowest number of rates is 10 , while the highest number is 540 (article 33, $\$ 1$ of the CC), the daily rate for the fine cannot be lower than 10 zloty nor exceed 2000 zloty (article 33, § 3 of the Criminal Code). Similarly to the Penal Fiscal Code fine, a court, when imposing a fine for a crime, takes into account the offender's income, personal and family conditions, property relations and property possibilities. In practice, some difficulties may arise in this respect, in particular with regard to perpetrators of criminal groups, perpetrators who rely on criminal activity for their livelihood. Their actual income is not documented, and they are often employed on low wages as unskilled workers. Moreover, they do not have any assets, they state they lack education, they do not document their professional career, they show financial burdens, and they show dependants.

An important institution in the Criminal Code is the so-called independent fine. Pursuant to article $33, \S 2$ of the Criminal Code, the court may impose a fine in addition to the penalty of imprisonment imposed for a crime, if the perpetrator committed an act in order to obtain a material benefit or if the perpetrator obtained a material benefit. Therefore, this institution will be very important in the case of committing acts under the Criminal Code and other criminal laws. We are well aware that activities related to the illegal production of tobacco products, for example, generate significant profits for the perpetrator. Therefore, in the case of imposing a sentence of imprisonment for acts under the act on the manufacture of ethyl alcohol and manufacture of tobacco products, the possibility of imposing a fine under article $33, \S 2$ of the $\mathrm{CC}$ is very important.

As a rule, the penalty of deprivation of liberty in the Penal Fiscal Code lasts at its shortest 5 days, and at its longest 5 years. It is measured in days, months and years (article 27, § 1 of the PFC). The Penal Fiscal Code provides for the penalty of restriction of liberty. However, it is not mentioned in the individual provisions of the detailed section of the Penal Fiscal Code. The provision of article 26, $\S 1$ of the Penal Fiscal Code states that if a fiscal offence is punishable by a penalty of deprivation of liberty, a court may instead impose the penalty of restriction of liberty, in particular if a penalty mentioned in article $22, \S 2$, points $2-6$ is simultaneously pronounced. The imposition of a custodial sentence shall not preclude the imposition of a fine for that offence in addition to a custodial sentence. The penalty of restriction of liberty consists of the obligation to perform unpaid, controlled work for social purposes or in deducting from $10 \%$ to $25 \%$ of remuneration for work on a monthly basis for a social purpose indicated by the court. This penalty can be imposed from 1 month to 2 years. The penalty of restriction of liberty will be imposed as in the Criminal Code, as the provision of article 26, $\S 4$ of the PFC refers to articles 34 and 35 of the Criminal Code. Thus, it also presented what the penalty of restriction of freedom under the Criminal Code is and how its length is established. The penalty of restriction of liberty has no significant practical significance in cases of fiscal offences. No penalty of arrest is envisaged for fiscal offences (in the case of common 
offences, such a penalty is provided for by the Polish Code of Administrative Offences), nor the penalty of restriction of liberty. The only penalty for a fiscal offence is a fine (article 47, $\S 1$ of the PFC). In the Criminal Code the penalty of deprivation of liberty lasts at its shortest for a month, and at its longest for 15 years (article 37 of the Criminal Code). For the crimes described in this study, the Criminal Code does not provide for penalties of any kind other than those discussed above.

\subsubsection{Penal Measures}

Sanctions for offences are not limited to fines only. The criminal liability of the offender for criminal offences should also be determined to a large extent on the basis of penal measures. The list of these should be as broad as possible. Contemporary research should be carried out to search for new forms of criminal law responses. It is not possible to discuss at this point the problem indicated, or the system of penalties and measures in Polish criminal law. The penal measures of the most importance for combating the practices discussed in this study are: forfeiture of objects (article 22, $\S 2$, point 2 of the PFC), recovery of the monetary equivalent of forfeiture of objects (article 22, $\S 2$, point 3 of the PFC), forfeiture of financial benefits (article $22, \S 2$, point 4 of the PFC), collection of the monetary equivalent of forfeiture of financial benefits (article 22, $\S 2$, point 4 a of the PFC), prohibition on conducting a specific business activity, performing a specific profession or taking a specific position (article 22, $\S 2$, point 5 of the PFC). Penalties have been calculated for aspects of a financial nature. This is in line with the research findings, in particular with regard to the fight against organised crime, where the most important issue remains the application of criminal reaction measures that will permanently deprive offenders of the financial resources to engage in illegal activities, sanctions that will make them unprofitable or at high risk of engaging in such activities.

The forfeiture of objects has such a function. In accordance with article 29 of the PFC, the forfeiture of objects includes: (1) objects directly derived from a fiscal offence; (2) tools or other movable property used or intended to be used to commit a fiscal offence; (3) packaging and objects connected with the subject of a fiscal offence in such a way that they cannot be disconnected without damaging any of these items; (4) objects whose manufacture, possession, circulation, storage, transport, transfer or shipment is prohibited. So, as can be seen from this list, the range of forfeiture is extensive. It includes the fruits of a fiscal crime (such as smuggled cigarettes) and the tools used to commit the crime. This category includes the means of transport by which tobacco products are smuggled. A specific category of items subject to forfeiture under the provisions of the Penal Fiscal Code covers the packaging listed in point 3 . The reasonableness of such a decision is confirmed by the example resulting from the subject matter discussed in this paper. Namely, the specificity of excise goods - cigarettes and tobacco-requires that confiscation also apply to the packaging in which they are contained. The more so, because false excise tax markings are often applied to such packaging. The last category is obvious. The goods listed in point 4 should not be in circulation, therefore the ruling 
on this category of confiscation restores the lawfulness of the condition. This will apply to smuggled cigarettes, for example. The provision of article $30, \S 1$ of the PFC introduces a rule that a court may order the forfeiture of objects only in cases provided for in the Penal Fiscal Code (optional forfeiture). A forfeiture is obligatorily pronounced if the Penal Fiscal Code so provides. The same article clarifies the offences for which forfeiture is pronounced. The provision of article $30, \S 2$ of the PFC enumerates the offences in respect of which the forfeiture of objects specified in article 29, points 1 to 3 of the PFC may be ordered. The provision of article $30, \S 3$ of the PFC specifies offences in respect of which a decision on forfeiture is obligatory in the case of the objects referred to in article 29, points 1-2 of the PFC, and in the case of the objects referred to in article 29, point 3 of the PFC, forfeiture is optional. In relation to the offences discussed in this study, mandatory forfeiture refers to the offences in Chapter 7 (offences against customs obligations and rules on foreign trade in goods and services) and items constituting the rewards of crime, tools and other objects used or intended to be used to commit the offence; otherwise, the forfeiture is optional. Nevertheless, the forfeiture of items whose manufacture, possession, circulation, storage, transport or shipment is prohibited (article 29 , point 4 of the PFC) is, in the case of the crimes referred to in article $29, \S 2-4$ of the PFC, obligatory (article $30, \S 6$ of the PFC). The rule is also that the court may decide, and in cases where the ruling is mandatory, the court shall decide on the forfeiture of objects: those directly originating from a fiscal offence (article 29, point 1 of the PFC); packaging and objects connected with the subject of a fiscal offence in such a way that they cannot be disconnected without damaging any of these items (article 29, point 3 of the PFC); objects whose manufacture, possession, circulation, storage, transport, transfer or transmission is prohibited (article 29, point 4 of the PFC) even if they are not owned by the perpetrator. An exception is a situation in which the perpetrator obtained the objects by way of a prohibited act - a crime or an offence (article $31, \S 3$ of the PFC). In relation to objects which are not the property of the perpetrator and which are tools or other objects constituting movable property used or intended to be used to commit a fiscal offence (article 29, point 2 of the PFC), the court can order their forfeiture if their owner or another authorised person anticipated that they could be used or intended to be used to commit a fiscal offence or could have foreseen it with due care required in given circumstances (article $31, \S$ 1a of the PFC). Article 31, 33 of the PFC provides for conditions under which a forfeiture decision is not possible. The first situation is that a forfeiture order would be disproportionate to the seriousness of the fiscal offence committed. The second is the fact of whether the public and legal fees were paid for the items at risk of forfeiture. However, forfeiture will be able to be ordered (will be ordered) if the public-law receivable is disproportionately low to the amount of the monetary equivalent of the forfeiture of objects or the forfeiture concerns objects that are tools or other items constituting movable property which served or was intended to commit a fiscal offence (article 29, point 4 of the PFC), or objects which were specially adapted to commit a prohibited act. The provisions of article $31, \S 6$ of the PFC stipulate that the enforcement of a decision on forfeiture of tobacco products shall be effected by destroying them. Pursuant to article $31, \S 7$ of the PFC, the costs 
of destroying objects for which forfeiture has been ordered are charged to the perpetrator.

The penal measure which is to replace the forfeiture of objects is the collection of the monetary equivalent of the forfeiture of objects (article 22, $\S 2$, point 3 of the PFC). This will be the case where it is not possible to order partial or total forfeiture. Pursuant to article $32, \S 1$ of the PFC, if it is impossible to make a decision in whole or in part on the forfeiture referred to in article 29 of the PFC, if the object has been destroyed, lost, hidden or cannot be acquired for other factual or legal reasons, the court shall order a penal measure to recover the monetary equivalent of the forfeiture of the object, unless the forfeiture concerns the objects specified in article 29, point 4 of the PFC. This provision indicates the cases in which it is impossible to pronounce a forfeiture decision. It should be stressed, however, that this list catalogue is open in the sense that it may refer to any situation (with the exception of the objects referred to in article 29, point 4 of the PFC) in which a forfeiture decision is impossible. For example, if the objects belong to a third party and the court does not pronounce a forfeiture, it is possible or necessary to apply article $32, \S 1$ of the PFC. The literature shows that the measure discussed is subsidiary in nature. ${ }^{55}$ This is confirmed by the comments made so far. In addition, it is worth noting that if the forfeiture decision is mandatory, the decision to recover the monetary equivalent of the forfeiture is also mandatory. ${ }^{56}$ The provision of article $32, \S 2$ of the PFC indicates that if the monetary equivalent of the forfeiture of objects cannot be determined precisely, it is approximated, and if several persons participated in the commission of a fiscal offence, they are jointly and severally liable for the payment of the monetary equivalent of the forfeiture of objects. It is not satisfactory that the provision of article $32, \S 1$ of the PFC excludes the possibility of recovering the monetary equivalent of forfeiture in the case of items whose manufacture, possession, turnover, storage, transport, transfer or shipment is prohibited. If the justification for this is that there may be difficulties in estimating the value of such objects in relation to such objects, ${ }^{57}$ then this is not a sufficient argument. Such a solution as in article $32, \S 1$ in fine of the PFC should concern not every case, but only those in which there is no possibility of making estimates or factual findings regarding such objects. However, if the facts show that the perpetrator had such objects at his disposal, it is also possible to estimate their value. Measures of fiscal repression must very restrictively implement the objective of depriving perpetrators of crimes, fiscal offences of benefits from committed acts, financial resources used to organise their unlawful practices.

Such an objective is to be achieved by further penal measures provided for in the Penal Fiscal Code. The provision of article 33, $\S 1$ of the PFC stipulates that if the perpetrator obtained, even indirectly, a material benefit from committing fiscal

\footnotetext{
${ }^{55}$ Postulski and Siwek (2004), pp. 301-302.

${ }^{56}$ Judgement of the Court of Appeal in Białystok of 19th March, 2015, case ref. II AKa 28/15, LEX 1663035.

${ }^{57}$ Such motives are indicated by: J. Raglewski, see: Raglewski (2007), p. 181.
} 
offences which is not subject to forfeiture of objects specified in article 29, point 1 or 4 of the PFC, the court (obligatorily) decides on a penal measure in the form of forfeiture of the material benefit. On the other hand, in the event that such a judgement cannot be made, a penal measure in the form of recovering the monetary equivalent of the forfeiture of material benefit is pronounced. The legal definition of a material benefit under article $53, \S 13$ of the PFC, that a material or personal benefit is a benefit both for oneself and for someone else, does not in fact reflect the complexity of this concept and the significance it assumes in relation to individual taxes. It is not a definition that meets the assumptions of the code's regulations and the provision, which aims to determine the meaning of a given term on the basis of a given act. In fact, the provision of article $53, \S 13$ of the PFC is an interpretative rule defining only the subjective scope of the concept, and not its meaning. The concept of material benefit (in article 33, $\S 1$ of the PFC there is talk only of such a benefit) should be determined in relation to each case, including criminal tax cases, and it is necessary to refer to tax regulations. Recovering the monetary equivalent in the case of a material benefit is possible (similarly as in the case of article $32, \S 1$ of the PFC) only after it has been established that the forfeiture of the material benefit is impossible. Article 33 introduces two presumptions. They are intended to ensure more effective implementation of the measures in question. They may be refuted by evidence to the contrary, which may be provided by the perpetrator or person concerned. The first is defined in paragraph 2 in such a way that in the case of a conviction for a fiscal offence, from which the perpetrator obtained, even indirectly, a material benefit of high value ${ }^{58}$ or a fiscal offence, from which the perpetrator obtained or could have obtained, even indirectly, a material benefit, threatened by a penalty of imprisonment, the upper limit of which is higher than 3 years, or committed in an organised group or association aiming at the commission of a fiscal offence for the benefit obtained from the commission of the offence, is considered to be property which the perpetrator took possession of (ownership, co-ownership, possession, lease) or with respect to which he obtained any title in a period of 5 years prior to committing the fiscal offence until the issue of even a non-binding judgement, unless the perpetrator or other interested person presents contrary evidence (article 33, $\S 2$ of the PFC). The second presumption stems from paragraph 3 of this article and concerns a situation in which the perpetrator transferred property to a natural or legal person or an organisational unit without legal personality, in fact or under any legal title. Following the adoption of such a regulation, property in the sole possession of a person or entity and his or her property rights shall be regarded as belonging to the perpetrator, unless it could not be presumed from the circumstances

\footnotetext{
${ }^{58}$ High value is considered by the Penal Fiscal Code to be a value which at the time of committing a prohibited act exceeds five hundred times the minimum remuneration-see article $53, \S 15$ of the PFC). Since 1st January, 2020, the minimum remuneration amounts to 2600 PLN, which gives the amount of 1,300,000 PLN as corresponding to a high value under the Penal Fiscal Code. The minimum remuneration for the work shall be established by way of a regulation of the Council of Ministers.
} 
surrounding their acquisition that the property, even indirectly, was derived from a criminal offence.

Similar regulations concerning forfeiture of objects, forfeiture of material benefits or equivalent are provided for in the relevant provisions of the Criminal Code. ${ }^{59}$ They will not be discussed here, because in relation to proceedings concerning crimes related to the illicit trade in tobacco products, the fiscal regulations are important in this respect. However, when discussing offences under the act on the manufacture of ethyl alcohol and production of tobacco products, attention was drawn to fundamental issues concerning forfeiture and differences introduced by the act.

The Penal Fiscal Code provides for a penal measure in the form of a ban on conducting specific business activity. Article $34, \S 2$ of the PFC refers to the offences for which it may be pronounced, and also indicates that this measure may be pronounced in the event of an extraordinary restriction of the penalty (article 38, $\S$ 1 and 2 of the PFC). This prohibition may last from 1 to 5 years (article 34, $\S 4$ of the PFC). This prohibition may fulfil its functions, with the proviso, however, that the decision on such a measure shall not affect persons operating on the grey market or organised crime. This measure can play a role, including in particular the prevention of phenomena such as also conducting illegal activities alongside legitimate activities connected with the manufacturing and marketing of tobacco products. In the course of the research carried out, such procedures were revealed. In such cases, the measure may be of great importance. An analogous measure is provided for in the Criminal Code (article 39, point 2 of the Criminal Code, article 41, § 2 of the Criminal Code).

\section{Procedural Rules}

Criminal procedural law in Poland does not provide for separate procedures or rules for proceedings strictly related to combating smuggling of cigarettes or other tobacco products. There are no specialised bodies to deal with such cases. As was already mentioned at the beginning of the study, the Penal Fiscal Code, on the basis of which most behaviours related to the issues discussed in the report are penalized, is a special proceeding concerning acts of a financial nature that is outside normal provisions. The special modes of a criminal trial are not clearly stated in Poland and they have also been subject to many changes, which have modified their original assumptions. It is possible to distinguish special modes, which are so directly defined by the Criminal Code and proceedings which, although not so called, are different in

\footnotetext{
${ }^{59}$ See (Buczkowski, Skuteczność odzyskiwania korzyści majątkowych uzyskanych przez sprawców przestępstwa - analiza przepadków orzeczonych na podstawie art. 45 k.k., 2010), pp. 221-263, also: (Buczkowski, Przepadek korzyści majątkowej po nowelizacji kodeksu karnego z 13 czerwca 2003 r. Wyniki badań aktowych 2007), pp. 26-42.
} 
nature. They should also be considered as special modes. The latter include proceedings in cases of fiscal offences and fiscal misdemeanours. This procedure also includes special modes in the first of the meanings cited here. Apart from the ordinary procedure, the Penal Fiscal Code provides for the following procedures: (1) with regard to granting permission for voluntary submission to liability; (2) mandatory; (3) with regard to absent persons; (4) a mandated procedure (it should not be equated with a ruling; the first three procedures and the ordinary procedure belong to judicial procedures).

Criminal proceedings in cases of fiscal offences and fiscal misdemeanours are regulated in Title II of the Penal Fiscal Code (Chapters 11-20, articles 113-177). Only in passing will it be noted that the Code also contains provisions concerning enforcement proceedings in cases of fiscal offences and fiscal misdemeanours (title III, chapters 21-24, articles 178-191). Some authors classify enforcement proceedings as criminal proceedings, hence the existence of the provisions of article 178-191 of the PFC. However, it should be assumed that such regulations maintain a high degree of separation from criminal proceedings. For these reasons, they will not be discussed in this report nor in the section on procedural issues.

Article 113, $\S 1$ of the PFC indicates that in proceedings in cases of fiscal offences and fiscal misdemeanours the provisions of the Code of Criminal Procedure apply accordingly ${ }^{60}$ It follows from this principle that the fiscal procedure is not a separate procedure ${ }^{61}$ The legislator only excluded the application of certain provisions of the Code of Criminal Procedure (article 113, $\$ 2$ and 3 of the PFC). Thus, the provisions concerning an injured party and mediation (article 113 , $\S 2$, point 1 of the PFC), article 325f of the Code of Criminal Procedure (article 113, § 2, point 2 of the PFC) are not applicable, while in cases of fiscal offences the provisions concerning preventive measures, searching for the defendant and an arrest warrant (article $113, \S 3$, point 1 of the PFC) and enumerated provisions (article 113, § 3, point 2 of the PFC) are not applicable. In cases of fiscal offences, the Code of Conduct for Infringements does not apply ${ }^{62}$ but only the provisions of the Code of Criminal Procedure. Thus, the model of proceedings in cases concerning fiscal offences and fiscal misdemeanours is based on the Code of Criminal Procedure with certain modifications, which may be of two types: (1) resulting from an explicit provision contained in title II of the PFC, which regulates a given institution differently; (2) resulting from the manner in which a given provision of the Code of Criminal Procedure will be applied due to the fact that we are dealing with a statement that the

\footnotetext{
${ }^{60}$ The act of 6th June, 1997, Code of Criminal Procedure, Journal of Laws of 2020, item 30, as amended.

${ }^{61}$ Unlike the repealed Fiscal Act of 1971 (the Act of 26th October, 1971, Journal of Laws of 1984, No. 22, item 103), which provided for a completely opposite principle, i.e. the application of the provisions of the Code of Criminal Procedure only in cases of an explicit referral. However, it cannot be omitted that there were many such references, and therefore, de facto the provisions of the Code of Criminal Procedure were applied.

${ }^{62}$ The Act of 21st August, 2001 - the Code of Conduct on Misdemeanours, Journal of Laws of 2019, item 1120, as amended.
} 
provisions are applied appropriately. The latter may mean: (1) application of provisions directly (without any change); (2) application of provisions with modifications resulting from the nature of the fiscal regulation; (3) non-application of provisions due to lack of such possibility, e.g. due to their contradiction with the fiscal regulation. The rules discussed here reveal a dilemma about how to regulate special proceedings. On the one hand, it is understandable that the aim is to harmonise the standards of criminal procedure. This is the way to read the solution adopted by the legislator in the current Penal Fiscal Code. On the other hand, it seems that the solutions consisting of (the simultaneous): (1) exclusion of certain provisions from application; (2) the introduction modifications in the standards resulting from given regulations; (3) referring directly to specific provisions of the Code of Criminal Procedure-this is done irrespective of the principle resulting from article $113, \S 1$ of the PFC, and may cause doubts concerning the application of a specific provision. There will be problems concerning the scope of the relevant application of a provision. As a consequence, it results in a requirement each time or relatively frequently to undertake an analysis of what regulations and to what extent they will be applied in proceedings concerning acts typified in the Penal Fiscal Code. This, in turn, not only prolongs the workload, but also causes interpretational difficulties, leads to inconsistencies in jurisprudence and even errors in the application of the law. The research carried out under the project shows that the long duration of criminal proceedings is a weakness in combating the illicit trade in tobacco products. Undoubtedly, the codified solutions discussed here are not conducive to the speed of proceedings and may be one of the factors extending them and affecting their effectiveness.

The provision of article 114, $\S 1$ of the PFC expresses the purpose of proceedings in cases of fiscal offences and fiscal misdemeanours consisting of the fact that the provisions of the code are aimed at shaping the proceedings in cases of fiscal offences and fiscal misdemeanours in such a way that the objectives of the proceedings in terms of compensating for the financial loss to the State Treasury, local government unit or other eligible entity caused by such an act are achieved. In the case of fiscal proceedings, this is an additional purpose in relation to those resulting from the applicable article $2, \S 1$ of the Code of Criminal Procedure. In view of this directive, we may risk the thesis that the legislator has opted for the enforcement of debts which should be paid by the perpetrator, and to a lesser extent it is a matter of repression. This is one of the elements which was supposed to distinguish criminal proceedings in cases of common crimes from fiscal proceedings. The separate procedure-allowing voluntary submission to liability and the wider possibilities of using this type of institution, slightly broader institutions than under the Criminal Code, institutions of refraining from punishing the perpetrator, caution under article $114, \S 2$ of the PFC (the body conducting the proceedings is to instruct about the rights of the perpetrator in the event of compensation for the financial damage caused) are an expression of this objective. It also results from the nature of a large number of acts detrimental to the fiscal interest, but it cannot be omitted, which also results from the previous part of the study, that in the Penal Fiscal Code we will find acts that do not consist of the depletion of public and legal receivables. It 
seems that Polish fiscal law has not developed a clear concept as to whether the emphasis should be on the enforcement of public-law debts or on repression.

Polish criminal proceedings consist of two main stages: (1) preparatory proceedings and (2) court proceedings (this procedure consists of two instances). Chapter 14 of the Penal Fiscal Code (article 133-135) deals with the competence of preparatory proceedings authorities. The bodies of preparatory proceedings are listed in article 118, $\S 1$ and 2 of the PFC. These are: the head of the tax office, the head of the customs and tax office, the Head of the National Treasury Administration, the Border Guard service, the police, the Military Police, the Internal Security Agency, and the Central Anti-Corruption Bureau. The public prosecutor wasn't included in this list. However, it should be included in the bodies of preparatory proceedings in view of the provisions of the Code of Criminal Procedure, which will be discussed later. The jurisdiction of the organs is presented in casuistic terms, i.e. to a large extent, it has been listed which crimes are dealt with by which individual authorities.

Pursuant to article 133, § 1 of the PFC, preparatory proceedings are conducted by: the heads of customs and tax offices, the heads of tax offices, the Head of the National Treasury Administration. These bodies are referred to as financial bodies in the pre-trial phase. These authorities form the National Treasury Administration. It is included in the structure of the Ministry of Finance, the Head of the National Treasury Administration reports to the Minister of Public Finance. As a general rule, with respect to offences related to the illicit trade in tobacco products, proceedings will be conducted by the heads of customs and tax offices. The Head of the National Treasury Administration may conduct any proceedings in cases of fiscal offences and fiscal misdemeanours disclosed within the scope of his activity, unless he transfers them to the authorities competent for such proceedings due to the subject of the act (article 133, $\S 1$, point 3 of the PFC). Both the head of the tax office and the head of the customs and treasury office may also initiate proceedings which do not fall within their competence. However, in such cases, once the evidence has been preserved, the authority is obliged to transfer the case to the competent authority for further prosecution.

The second group of authorities conducting preparatory proceedings, the so-called non-financial bodies of preparatory proceedings, are: the Border Guard service with respect to selected fiscal crimes and fiscal offences (article 134, § 1 , point 1 of the PFC); and also with respect to crimes disclosed within the scope of its activity: the police (article 134, § 1, point 2 of the PFC); the Internal Security Agency (article 134, $\S 1$, point 3 of the PFC); and the Central Anti-Corruption Bureau (article 134, § 1, point 5 of the PFC). The Penal Fiscal Code introduces an obligation to exchange information on pending proceedings between authorities, in particular non-financial and financial authorities. In practice, in relation to crimes related to illicit trade in tobacco products, preparatory proceedings are conducted by the Border Guard service and the police. It is worth noting that the police have a Central Investigation Bureau of the Police, which deals with combating organised crime. This unit is therefore intended to combat criminal groups that are engaged in activities such as illicit production and trade in tobacco products. An authority in 
preparatory proceedings for treasury cases also includes a prosecutor, who can conduct preparatory proceedings in cases concerning fiscal offences and fiscal misdemeanours in any case (article 134a of the PFC, article 298, $\S 1$ of the Code of Criminal Procedure in connection with article $113, \S 1$ of the PFC). If a prosecutor does not conduct preparatory proceedings, he or she shall supervise them (article 326 of the Code of Criminal Procedure in connection with article 113, $\S 1$ of the PFC, article 151c, $\S 2$ of the PFC). In practice, preparatory proceedings are usually conducted by the authorities indicated in article 133 of the PFC (financial bodies of preparatory proceedings), article 134 of the PFC (non-financial bodies of preparatory proceedings), and the prosecutor supervises such proceedings, performs activities reserved for him/her by law (e.g. filing motions for provisional detention, issuing a security decision).

Court proceedings in cases of fiscal offences and fiscal misdemeanours fall within the jurisdiction of district courts. In the second instance, district courts decide. Pursuant to article $121, \S 1$ of the PFC, apart from the prosecutor, the public prosecutor in court is the body that makes and supports the indictment. The competence to do so is granted by the provision of article $121, \S 2$ of the PFC, but only in cases of fiscal offences. The prosecutor is responsible for filing and supporting a bill of indictment in cases of fiscal offences. The provision of article 122, $\S 1$ and 2 of the PFC defines the financial powers of the bodies of preparatory proceedings. The aforementioned provision determines the powers provided for the prosecutor to be vested in the bodies of preparatory proceedings.

In cases concerning crimes under the Criminal Code or other penal acts, as a rule, preparatory proceedings are conducted by a prosecutor or the police. The powers of the police are also vested in other bodies within the scope of their competence (the Border Guard service, the Internal Security Agency, the National Treasury Administration, the Central Anti-Corruption Bureau, the Military Police and other bodies, if such a special provision provides for such). Court proceedings in criminal cases belong to the jurisdiction of the regional court or the district court in the first instance. The provisions of the Code of Criminal Procedure shall determine the material jurisdiction. Generally, the jurisdiction of a regional court ruling in the first instance includes cases of serious crimes. The decisions issued by the district court are subject to appeal to the regional court, and the decisions issued by the regional court in the first instance to the court of appeal. The regional court as the court of first instance will adjudicate in criminal tax cases in such a procedural arrangement where the indictment includes crimes falling within the jurisdiction of the district court (there will be a group of fiscal crimes and fiscal offences here) and the jurisdiction of the regional court (common crimes reserved for consideration by this court). The provisions on joint cases will apply in such cases.

In criminal cases of a financial nature, the use of a security on property as a measure is of significant importance. Such an institution is known to the Code of Criminal Procedure as well as the Penal Fiscal Code. The purposefulness of adjudicating on security on property is justified by the fact that such security, at an early stage of preparatory proceedings, may in many cases be the only possibility of recovering property derived from crime, subject to forfeiture or other penal 
measures. Compared to the security which may be applied under the Code of Criminal Procedure, the security under the Penal Fiscal Code has a wider scope of subject matter. Pursuant to article 131, $\S 1$ of the PFC, in the event of a fiscal offence, the following penal measures may be secured: forfeiture of objects (article 22, $\S$ 2 , point 2 of the PFC), collection of the monetary equivalent of forfeiture of objects (article 22, $\S 2$, point 3 of the PFC), forfeiture of material benefits (article 22, $\S$ 2, point 4 of the PFC), collection of the monetary equivalent of forfeiture of objects (article 22, § 2, point 4a of the PFC), the obligation to return financial benefits and the obligation to pay public law dues that have been reduced due to a prohibited act. A prerequisite for a securing order is a well-founded fear that, without such a securing order, the enforcement of the securing order in respect of the said institutions will be impossible or significantly impeded. The provision of article $291, \S 1$ of the Code of Criminal Procedure (this provision is also applied in the fiscal procedure) allows for securing: a fine, forfeiture, cash benefit, compensatory measure, return to the wronged party or other entitled entity of the financial benefit that the perpetrator has obtained from the committed offence, or its equivalent. The Penal Fiscal Code also allows security to be made on the property of an entity held liable for an auxiliary penalty of a fine, recovery of the monetary equivalent of the forfeiture of objects, forfeiture of a material benefit, recovery of the monetary equivalent of the forfeiture of a material benefit, and the obligation to return a material benefit (article 131, § 3 of the PFC).

The police, the National Treasury Administration, the Border Guard service, as well as special services such as the Internal Security Agency and the Central AntiCorruption Bureau may conduct operational and exploratory activities. The powers to do so are determined by individual acts regulating the activities of the aforementioned services and bodies. There is no room for quoting all these regulations in this paper. The concept of operational and exploratory activities is not defined by law. It should be understood as a non-confidential, non-procedural activity of authorised services, which is aimed at ensuring public order and state security. ${ }^{63}$ The functions of such activities remain important. They are as follows: the exploratory function, i.e. the investigation of criminal environments and criminogenic phenomena; the discovery function, i.e. the disclosure of offences and the identification of perpetrators; the evidentiary function; the preventive function, i.e. the prevention of offences and threats. ${ }^{64}$ Operational and exploratory activities may be implemented after certain statutory conditions have been met and, if required by law, after obtaining the consent of the competent authorities. The aforementioned functions make operational and exploratory activities very important and sensitive to the work of the services. Sometimes they are very complex operations that are legally and technically demanding. There is no definitive list of operational activities. We may distinguish operational activities such as, but not limited to: operational control; use of technical means such as tapping or monitoring; correspondence control;

\footnotetext{
${ }^{63}$ Czeczot and Tomaszewski (1996), p. 67.

${ }^{64}$ Tarach (2006), p. 17.
} 
collaboration with information sources; controlled purchases; controlled acquisition or handing over; submission of proposals for the giving or receiving of a financial benefit; controlled delivery; secret agent; or special operation. The issue of operational and exploratory activities is very broad. It also gives rise to controversy as to the legality of evidence obtained using certain operational and exploratory methods. However, particularly in the fight against organised crime, as is the case with this problem, the use of operational and exploratory methods is an indispensable part of the services and must, in principle, remain a fundamental instrument in the fight against organised crime of this nature. In the course of the research conducted, it was established that in the assessment of the services, the scope of the subject matter of operational and exploratory methods is set at a satisfactory level. What is needed, however, is to provide better and better equipment and resources to carry out such activities. It is, of course, a reflection of what has already been pointed out that criminal groups use very advanced, modern technical means. Therefore, the services must have adequate technical resources. Human resources and the preparation of such operations in legal terms are also important, so that the information and evidence obtained can be used in a legal process in the future and constitute a complete body of evidence.

\section{Cooperation Between State Authorities}

A very important practical element, noticed in research interviews conducted with officers of the Central Investigation Bureau of the police and the National Treasury Administration, is cooperation between services. As can be seen from the procedural issues presented above, the proceedings concerning the issue discussed may in fact be conducted by several authorities. In the course of the research, attention was paid to whether it does not cause difficulties in prosecuting fiscal crimes or fiscal offences. The answer to this question is negative. The authorities competent for conducting pre-trial investigations share their specific competence. For example, the Central Investigation Bureau of the police is responsible for combating organised crime, the Border Guard service is responsible for crimes committed in connection with crossing the border, the Voivodship Police Headquarters conducts, among others, cases concerning the marketing of illegal tobacco products in the country, customs and tax offices examine strictly tax-related issues. Respondents argue that cooperation between these services is progressing well and that there is no need to introduce changes in this respect, in particular to consolidate the powers to conduct proceedings to combat crime involving illicit trade in tobacco products. In the course of the research, the need to develop and improve cooperation with the prosecutor was pointed out. As mentioned above, the prosecutor supervises ongoing preparatory proceedings. Less frequent are situations in which the prosecutor conducts an investigation, and even if a significant scope of activities is entrusted to other bodies (e.g. heads of customs and tax offices, the police, etc.). There are no procedural or organisational rules on what the prosecutor's supervision over the proceedings 
conducted should look like. It cannot be precluded that the problem revealed should constitute an encouragement to reflect on how the prosecutor's supervision over conducted proceedings in the scope of the crime in question should be shaped and performed, and what tasks (apart from those explicitly reserved for him by the provisions of the Code of Criminal Procedure) the prosecutor should perform. Aspects of international cooperation in combating crime related to illicit trade in tobacco products were also analysed. The conclusion is that there are instruments in place to ensure a general level of cooperation, i.e. primarily the legal basis. There is no need to create an organisation to coordinate such cooperation. However, there is a need (taking into account the experience of Polish authorities) to develop operational cooperation between services of different countries, the exchange of information at such a level, and the integration of communities and joint training. The aim is to ensure the possibility of direct cooperation between officers from units in different countries, which is supposed to lead to quick action.

\section{Criminological Issues}

\subsection{Introduction}

Poland, as a country with one of the longest external borders of the European Union in the east of the Community, is particularly exposed to crime associated with the smuggling of goods. The eastern border of Poland, which is at the same time the eastern border of the European Union, is threatened with high levels of smuggling, production and distribution of tobacco products. The removal of stationary border controls on the Polish section of the internal EU/Schengen border and the persisting disproportion in excise prices between countries of origin and destination have resulted in an increase in the production and smuggling of tobacco products on a large scale by organised criminal groups.

\subsection{Categories of Crime Linked to the Trade in Tobacco Products}

Crime in the broader context of trade in tobacco products can generally be divided into three categories:

- acts related to the smuggling or illegal import of cigarettes into Poland without Polish excise tax markings for the purpose of their distribution in Poland or export to other countries;

- acts relating to the illegal manufacture of cigarettes, their marking with counterfeit trademarks and excise duties, and the trade in such cigarettes;

- acts related to the illegal trade in tobacco. 
All of the above categories are primarily linked to financial losses incurred by the state as a result of lost tax revenues.

The former leads to a reduction in excise duty primarily as a result of the fact that tobacco products imported into Poland are not marked with excise tax markings. In addition, other public law liabilities, in particular VAT and customs duties, are depleted.

The second category covers illegal tobacco factories, where production takes place without quality control, as well as without any of the formal permits required for this type of activity. These acts include not only counterfeiting of tobacco products but also counterfeiting of the external appearance of the product, including in particular tobacco product packaging, cigarette trademarks and the failure to mark products with excise duty markings or the use of counterfeit markings.

The third category is linked to a change in the rules governing the production and purchase of raw tobacco in member states of the European Union. This has resulted in an increase in the illegal trade in unprocessed tobacco leaves (loose tobacco).

\subsection{Statistical Data}

An analysis of data is hampered by the fact that statistics maintained by police, prosecutors, courts, customs officers and border guards do not distinguish illegal trade in tobacco products as a separate category of offences. Such acts fall into larger categories such as: smuggling, handling, failure to mark products with excise stamps; the production, import or trade in excise goods without official verification; the manufacture of tobacco products without the required entry in registers; or a reduction in VAT or customs duties due. Therefore, an analysis can only be based on data provided by these individual authorities or services and as such the data used does not have the attributes of data enabling an estimation of the scale of the phenomenon for the whole country (Table 1).

In addition, the personal data of the perpetrators of crimes related to the illegal trade in tobacco products is not collected separately, and therefore it will not be possible to analyse this data within the framework of this study.

In Poland, from 500 million to almost 800 million illegal cigarettes are uncovered each year as a result of inspections carried out by tax inspectors, the police, border guards and customs officers.

The upward trend in seizures of cigarettes began in 2013 and continued until 2016, which was a record year in terms of the number of illegal cigarettes discovered by the services. In the following years (2017-2018), the number of cigarettes seized decreased significantly: in 2017, from about $10 \%$ for the police to $30 \%$ for the National Tax Administration (NTA), while in 2018, the trend was even worse, from over $26 \%$ for the NTA to almost $40 \%$ for the police.

In the case of tobacco and dried tobacco seizures, the peak period was 2015 , when more than $2,500,000 \mathrm{~kg}$ of these goods were seized, followed by a significant 
Table 1 Preparatory proceedings initiated by the Border Guard Service in relation to a violation of the provisions of the Penal and Fiscal Code in the years 2011-2018

\begin{tabular}{l|r|r|r|r|r|r|r|r|r}
\hline Year & 2011 & 2012 & 2013 & 2014 & 2015 & 2016 & 2017 & 2018 & Total \\
\hline $\begin{array}{l}\text { Number of preparatory } \\
\text { proceedings instituted }\end{array}$ & 3186 & 2463 & 2342 & 1948 & 2541 & 2190 & 2124 & 1730 & 18,524 \\
\hline \begin{tabular}{l} 
Including: \\
\hline $\begin{array}{l}\text { In conjunction with } \\
\text { organised crime }\end{array}$
\end{tabular} & 25 & 32 & 16 & 14 & 18 & 19 & 22 & 18 & 164 \\
\hline $\begin{array}{l}\text { In conjunction with the } \\
\text { act on Industrial Prop- } \\
\text { erty Law }\end{array}$ & 3 & 0 & 6 & 15 & 5 & 5 & 5 & 4 & 43 \\
\hline $\begin{array}{l}\text { In conjunction with the } \\
\text { act on the Production of } \\
\begin{array}{l}\text { Ethyl Alcohol and } \\
\text { Manufacturing of } \\
\text { Tobacco Products }\end{array}\end{array}$ & 5 & 0 & 8 & 7 & 4 & 14 & 10 & 13 & 61 \\
\hline
\end{tabular}

Source: Border Guard Service

decrease in seizures in subsequent years (2016-2017), amounting to as much as 54\% in 2017 in the case of the Border Guard Service.

However, it should be stressed that this data does not indicate a decrease in the effectiveness of activities undertaken by services involved in combating tobaccorelated crime (police, Border Guard Service, National Treasury Administration), but rather indicates a certain trend resulting from the tightening of the eastern border of Poland (which is also the eastern border of the European Union/Schengen) and the relocation to the south of Europe (primarily to the Balkan countries: Bulgaria, Romania, Greece and the Mediterranean countries) of the main routes for the smuggling of tobacco products manufactured in eastern European countries (Belarus, Russia, Ukraine) (Fig. 1).

A similar trend can be observed with illegal cigarette production in factories in Poland, where domestic production is gradually being exported from Poland to western European countries, although according to statistics, 36 illegal cigarette factories were discovered and shut down in Poland in 2018, compared to only 18 in 2015.

In 2016, the public prosecutor initiated 2672 preparatory proceedings concerning crimes related to the illegal trade in cigarettes, in which:

- charges were brought against 3496 suspects,

- 178 people were temporarily arrested,

- 1796 indictments were filed,

- 2573 people were charged and subsequently convicted,

- 1471 cases were concluded with judgements,

- 430 proceedings were discontinued.

The total value of public and legal receivables at risk of depletion in cases concluded in 2016 with bills of indictment amounted to 3,117,050,003 PLN (approximately 718,000,000 EUR). 


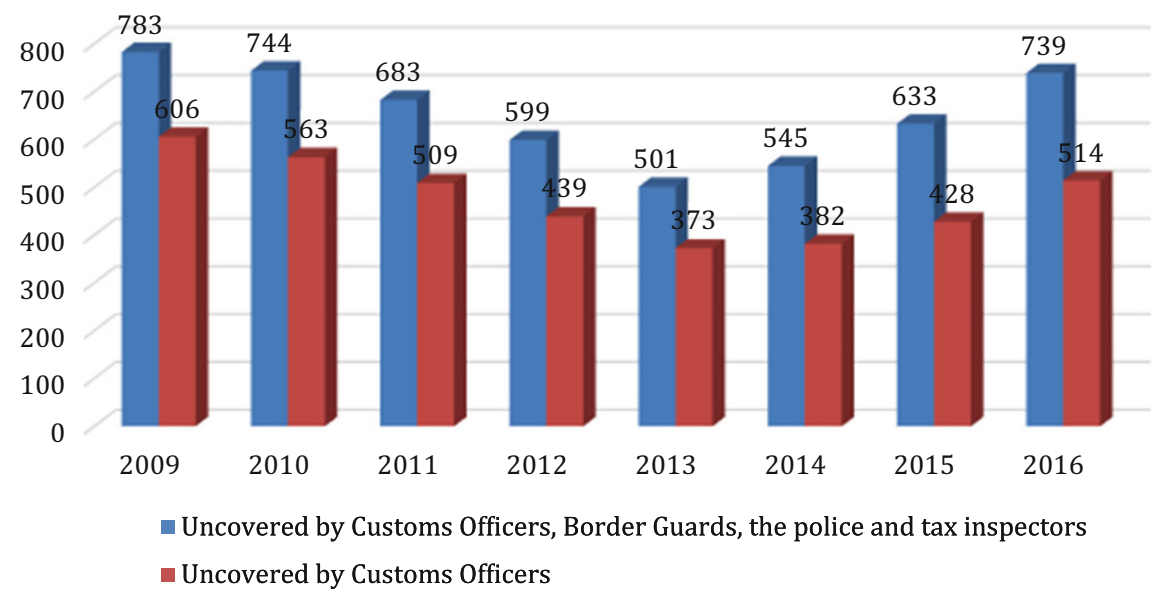

Fig. 1 The number of illegal cigarettes discovered in Poland in 2009-2016 (in millions of cigarettes). Data source: Report on the state of national security 2016, Warsaw, Ministry of Internal Affairs and Administration

For comparison, it should be noted that in 2010 in all public prosecutor's offices there were 1984 preparatory proceedings concerning crimes related to tobacco products (smuggling, handling of stolen goods, the illegal production of tobacco products), of which:

- 1130 proceedings were concluded with a bill of indictment,

- 1722 people were charged,

- 274 cases were dismissed,

- 20 proceedings were concluded with a refusal to initiate proceedings,

- 472 cases were concluded in some other manner (suspension of proceedings, transfer to customs officers, etc.).

The total value of public and legal receivables at risk of depletion and damages suffered by other entities in all cases concluded in 2010 with bills of indictment amounted to 541,635,018 PLN (approximately 135,280,238 EUR).

It should be noted that there has been a steady decline in the share of illegal cigarettes in the domestic tobacco market since 2015. It is estimated that in the second quarter of 2015 it amounted to 19\%, while in the third quarter of 2018 it fell to just over $11 \%$.

As a result, the number of legally available tobacco products increased and the state budget's excise tax revenue increased despite the fact that the excise tax rates applied remained unchanged (Fig. 2).

Due to the widespread use of modern methods of smoking involving the use of heating devices, the cartridges for these devices may also be smuggled, mainly from the territory of Ukraine, where the factories are located, and at least three times more money on the smuggled cartridges can be made on the difference in price between 


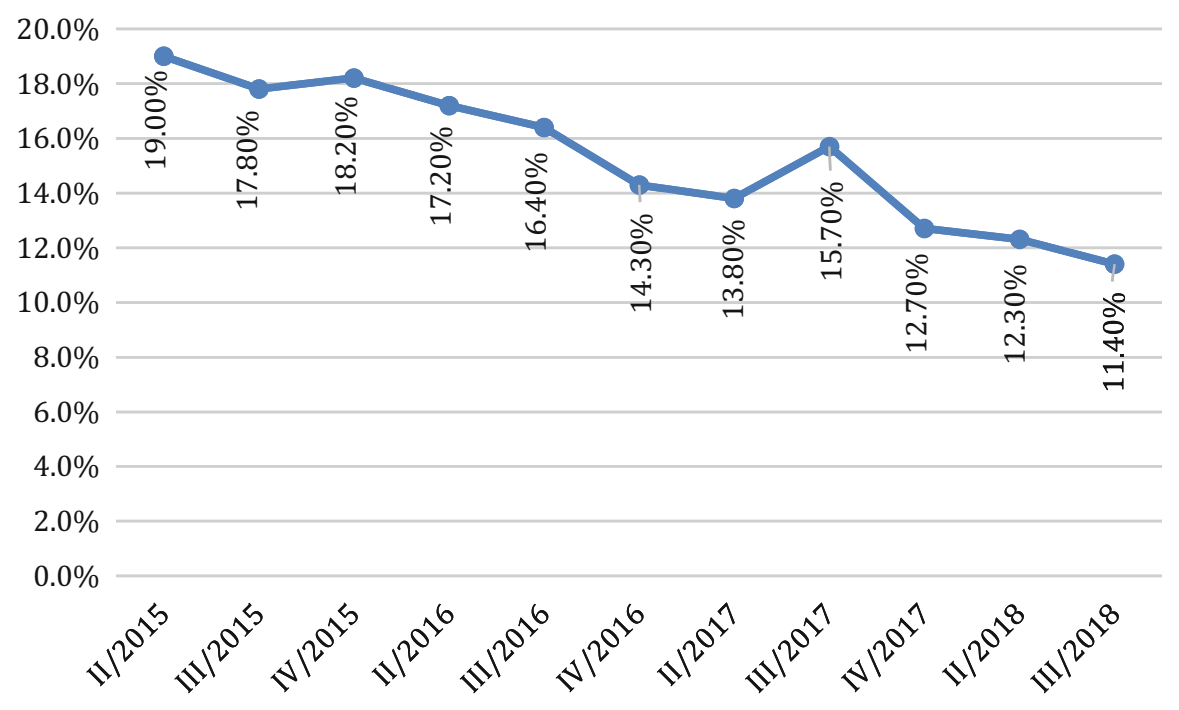

Fig. 2 The share of illegal cigarettes in the domestic tobacco market between 2015 and 2018 (\%). Data source: The Ministry of Finance

the Ukrainian and Polish markets. When smuggling them to western European countries, a smuggler's profit may be even higher.

The data for 2010-2013 shows that when Poland was a destination country for smuggled tobacco products, the source of their origin (the place from which they came to Poland) was primarily Belarus, Ukraine, Russia, but also Lithuania, Latvia and China. When Poland was a country from which tobacco products were smuggled to other countries, the main destinations were Germany, Italy, the United Kingdom, the Czech Republic and Sweden. However, when Poland was a transit country for smuggled products from Ukraine, Russia, Lithuania and Latvia, the destination countries were Germany, the Czech Republic, the United Kingdom, Belgium and Italy.

It should be noted that in connection with the sealing of Poland's eastern border (e.g. through the use of goods scanners and new technical surveillance measures on the border), an increase in illegal production of tobacco products has been observed in the country for several years. This is connected with the lower costs for the organisers (mostly organised crime groups) than is the case for smuggling from neighbouring countries. Production in domestic factories is mostly directed to western European markets, in particular the German and British markets, wheredue to differences in tobacco prices - the profitability of the whole process is very high. 


\subsection{Modus Operandi}

The specific nature of the eastern border of Poland and the European Union means that the main route for tobacco smuggling into the territory of the Community is by land. Polish border crossing points with Belarus, Ukraine or Russia are used for this purpose (on the Polish-Lithuanian border, due to the presence of both countries in the Schengen structures, there are no border controls although, and this should be noted, there are still some discoveries of illegal cigarettes) and the so-called "green border" in the mountainous areas of the Bieszczady mountains on the border between Poland and Ukraine, where, due to the physical terrain of the area, it is difficult to conduct very thorough inspections, and the river Bug on the border.

It should be emphasized that tobacco products are imported mainly from over the eastern border of Poland and the target countries for this type of smuggling are the countries of western Europe: Germany, Belgium, Italy, and the United Kingdom). Prior to 2010 tobacco products were mainly smuggled from the territory of Ukraine, however since 2011 Belarus has become the dominant country for this type of criminal activity. According to data from 2018, as much as 54\% of the tobacco products seized by Polish customs officers were smuggled from Belarus, 29.4\% from Ukraine and the remaining $16.6 \%$ were mainly from Russia, China and the United Arab Emirates.

The mechanisms used to smuggle tobacco products include road transport, including lorries, rail transport, petty smuggling by private individuals (smugglers commonly referred to as "ants") carrying tobacco products across borders or transporting them using their private cars. A commonly used method for cigarette smuggling at road border crossings is to transport cigarettes in structural and non-structural compartments of cars and vans (e.g. in a converted fuel tank, the floor or other elements of a vehicle's fixtures and fittings).

Tobacco smuggling in private cars accounted for more than $82 \%$ of the tobacco products discovered and confiscated by Polish customs officers in 2018. In the case of lorries, confirmed smuggling accounted for less than $2 \%$ of all confiscated tobacco products and for more than $5 \%$ in the case of buses.

The Polish Customs and Border Protection Services points to a reduction in the risk of smuggling of tobacco products concealed in railway wagons (in 2018 it accounted for only $1.8 \%$ of confiscated tobacco products). However, the Border Guard Service still uncovers cases of smuggling of such products hidden in the technological elements of wagons and in bulk and general cargo being transported. The discovery of tobacco products smuggled on a freight train results means there are no persons who can be held criminally or fiscally liable.

Smuggling through mountainous areas on the border between Poland and Ukraine, due to the terrain, makes it impossible to use road transport on a larger scale; therefore, the smuggling of tobacco products using this means of transport is quantitatively smaller, although in recent years - due to the tightening of controls at border crossings - there has been an increase in reported cases of smuggling through the so-called "green border" of the two countries indicated above. The river Bug is 
also used for smuggling. Tobacco smuggling is carried out with the use of both lightweight floating equipment and by swimmers and persons pulling bags behind them.

Tobacco smuggling across the "green border" is becoming increasingly popular among organised crime groups and is a channel that is increasing being used. This may be evidenced by the excise goods discovered by border guards, prepared for transport in the vicinity of specific border marks. It cannot be ruled out that organised crime groups, through the identification of convenient transit points across the state border, will later use them as proven mechanisms for the smuggling of narcotic substances or weapons, for example.

Small flying objects (microlights, drones) are also used for tobacco smuggling. This is the fastest means of transport and, furthermore, it does not require the involvement of many people in the whole process. In the case of microlights, cigarettes are dropped from a low height and then recovered by smugglers. Up to 10,000 packs of cigarettes can be dropped at a time using this means of transport. Since 2013, the use of small aircraft has been one of the most common ways of smuggling tobacco products on the Polish-Ukrainian section of the state border among criminal groups. Flights are usually performed at night, in good weather conditions, with no rainfall, no cloud cover, very little wind and good visibility.

The removal of stationary border controls on the Polish sections of the internal border of the European Union/Schengen and the persistent disproportion in the prices of excise goods between countries of origin and destination, as well as the introduction of visa fees for third country nationals and the restrictions on the importing of cigarettes up to 40 cigarettes, resulted on the one hand in a reduction in smuggling by private individuals and on the other hand in an increase in the production and smuggling of tobacco products by organised crime groups operating in Poland.

The procedures for the transit of goods through Poland are also used for the purposes of tobacco smuggling. This involves their removal from customs supervision and fictitious confirmation of their export to the European Union. As a result, tobacco products which are listed in customs systems as having left the Polish customs territory actually remain in the country, from where they can be smuggled into another country. This type of smuggling is used primarily by organised criminal groups, as it requires significant financial resources (e.g. to pay for two methods of transport or payment for falsifying transport documents or vehicle registration documents) and good logistics.

Organised crime groups are also involved in the illegal production of tobacco products in Poland. Their involvement results from the specific nature of this type of crime requiring the existence of a structure involving many people, incurring specific financial outlays (purchase of dry tobacco leaves, payment of employees, the rental of buildings) and providing appropriate technical resources (machines for the production of products, packaging, and means of transport). Illegal tobacco product factories are often located close to major transport routes, which facilitates their distribution, and also close to legally operating entities, which enables the concealment of increased traffic in their vicinity. The machinery for the production of illegal 
tobacco products is sourced from bankrupt factories in Bulgaria together with their machine operators. One novelty is the use by organised groups of mobile mini factories organised in truck trailers, which makes it difficult for law enforcement authorities to detect them.

\section{Conclusions}

As can be seen from the above analysis, the legal regulations that may address the issue of illicit trade in tobacco products are very extensive. This concerns both the area of criminal law and tax regulations, an analysis of which is an indispensable element of making arrangements for the criminal liability of perpetrators for the crimes discussed. The provisions of the specific part of the Penal Fiscal Code, in which particular crimes were penalised, should be reviewed by the legislator in terms of their usefulness for the effectiveness of combating specific crimes. As it has been shown above, in the category of tax crimes and tax misdemeanours one can find such acts, which in fact contain (absorb) others. In addition, tax and fiscal law should not be subject to such frequent changes. Moreover, the legislator must remember that when amending the provisions of the latter, it is necessary to introduce appropriate changes to the Penal Fiscal Code, so as not to lead to inconsistent regulations.

The question arises here whether such a shaping of the model of responsibility for fiscal offences is appropriate. Questions also need to be asked as to whether the system is coherent. Responsibility for minor acts (low depletion/exposure to depletion, low value of goods/services committed by natural persons not linked to the activities of criminal groups) and liability for formal crimes (violation of tax law obligations) is not clearly separated from responsibility for acts of high social harmfulness (very high depletion/exposure to depletion, high value of goods/services, crimes committed by organised criminal groups, crimes committed in recidivism). Criminal repression for this type of crime should increase significantly in such a way as to make it unprofitable for perpetrators to carry out large-scale activities. While there are criminal reaction measures in place to deprive offenders of the benefits of criminal activity, an improvement should take place in terms of obtaining information and searching for assets hidden by offenders. In addition, it is necessary to use the institution of securing property. The only postulate for changes in this respect is that the criminal measure in the form of recovering the monetary equivalent of the forfeiture should include the objects referred to in article 29, point 4 of the PFC (objects whose manufacture, possession, marketing, storage, transport, transfer or shipment is prohibited).

We also see, on the basis of the analyses made, that the problem of illegal trade, production, smuggling of cigarettes or other tobacco products is perceived by the legislator and law enforcement authorities only as a phenomenon of a fiscal nature, detrimental to the legal rights and interests of the state, or the interests of the European Union of such a nature. However, this problem should also be seen in 
the light of how it affects the health, life of citizens and the functioning of the economy (i.e. a broader aspect than just taxation should be taken into account).

The aspects relating to the conduct of proceedings should be examined in greater depth. It cannot be ruled out that such research would lead to the conclusion that serious systemic changes are necessary with regard to the conduct of proceedings in cases concerning fiscal offences. Reasonable questions arise about the effectiveness and economics of proceedings in frequently occurring agreements where tax proceedings are conducted, and then (most often as a result of irregularities found in the proceedings) fiscal proceedings are initiated. The scope of the two proceedings overlaps to a large extent. Solutions should be sought in which a single procedure would be conducted in the area of fiscal liability and tax liability. The more so as the tax authorities are also in many cases competent to conduct proceedings for fiscal offences and fiscal misdemeanours.

Looking at the operational powers of the authorities, it should be said that this is set at an appropriate level. However, it is necessary to undertake actions related to effective use of operational and exploratory measures in the technical aspect (equipping the authorities of proceedings with the necessary technologically advanced equipment, corresponding to the measures used by perpetrators of crimes), logistic aspect (creating good working conditions for officers, ensuring appropriate human resources to perform tasks), and organisational and legal aspects. Operational and exploratory methods are very important in the fight against organised crime. At the same time, cooperation between the services of the Member States of the European Union should be developed at the level of operational cooperation, as well as with the services of other countries neighbouring Poland.

Among the most serious difficulties related to combating tobacco-related crime, it is worth mentioning the following:

- the cross-border nature of the activities of organised crime groups;

- the dispersal of criminal activity into different locations at different stages of the activity: preparation, production and distribution of criminal products (different locations for the collection and production (factories) and different locations for storage facilities);

- the non-unified legal norms at the level of EU Member States as regards to the classification of crimes related to the production and smuggling of excise goods and specific activities (non-unified penal and fiscal policy);

- the simultaneous participation of persons conducting legal economic activity related to the production and trade in excise goods in the practice (e.g. conducting legal tax warehouses, customs warehouses, and using them to store goods from an illegal source or production of tobacco products outside supervision in a legal factory).

Combating the illegal trade in tobacco products would make it easier:

- to strengthen international and cross-border cooperation, with particular emphasis on intensifying contacts with the services responsible for combating excise crime, 
- to cooperate with tobacco companies-primarily for training purposes, with a view to increasing specialist knowledge in tobacco labelling and traceability,

- to introduce more effective legal solutions to combat excise crime.

It should be pointed out that criminal liability for cigarettes, unlike for the manufacture and trade in narcotics, is also disproportionately low in relation to the profits, which encourages this type of criminal activity. Such criminal activities are generally not seen as highly socially harmful, which is also reflected in the low penalties imposed for offences related to the illegal trade in tobacco products.

Finally, it is worth noting that combating crime of the character discussed requires significant financial outlays, investments in human resources (posts, training, working conditions and wages) and tools for the implementation of demanding tasks. Crime related to the illicit trade in tobacco products is very well organised. Criminal groups have large financial resources, advanced techniques, and are able to adapt quickly to the prevailing conditions, especially in terms of modifying their methods of action in case of detection by the services (this is evidenced by the variety ways used for smuggling, production, and concealing criminal activity).

At the same time, it is also worth taking action to raise citizens' legal awareness and develop a negative attitude towards products from illegal production and smuggling. For the crime in question, social consent to the phenomena is not without significance. Of course, this is not about the phenomenon of organised crime, because it is not accepted by society, but about the phenomenon of purchasing products on the grey market, which is already receiving much more lenient views.

\section{References}

Buczkowski K (2007) Przepadek korzyści majątkowej po nowelizacji kodeksu karnego z 13 czerwca 2003 r. Wyniki badań aktowych. Biuletyn Polskiego Towarzystwa Kryminologiczny im. prof. Stanisława Batawii 16:26-42

Buczkowski K (2010) Skuteczność odzyskiwania korzyści majątkowych uzyskanych przez sprawców przestępstwa - analiza przepadków orzeczonych na podstawie art. 45 k.k. In: Siemaszko A (ed) Prawo w działaniu, vol 8. Oficyna Naukowa, Warszawa

Buczkowski K (2013) Przestępstwa skarbowe jako czyny bazowe w konstrukcji prania pieniędzy. In: Rzepliński A, Rzeplińska I, Niełaczna M, Wiktorska P (eds) Pozbawienie wolności - funkcje i koszty. Księga Jubileuszowa Profesora Teodora Szymanowskiego. Wolters Kluwer Polska, Warszawa

Buczkowski K (2017) Cudzoziemcy jako sprawcy przestępstw gospodarczych - wyniki badań aktowych. In: Klaus W, Laskowska K, Rzeplińska I (eds) Przestępczość cudzoziemców. Aspekty prawne, kryminologiczne i praktyczne. Wydawnictwo Naukowe Scholar, Warszawa

Czeczot Z, Tomaszewski T (1996) Kryminalistyka ogólna. Comer, Toruń

Flemming M, Kutzmann W (1999) Przestępstwa przeciwko porządkowi publicznemu. Rozdział XXXII kodeksu karnego. Komentarz. C. H. Beck, Warszawa

Konarska-Wrzosek V, Oczkowski T, Skorupka J (2013) Prawo i postępowanie karne skarbowe. Wolters Kluwer Polska, Warszawa

Łabuda G (2017) Kodeks karny skarbowy. In: Kardas P, Łabuda G, Razowski T (eds) Komentarz. Wolters Kluwer Polska, Warszawa 
Laskowska K (2017) Granica państwa jako miejsce popełniania przestępstw przez zorganizowane grupy przestępcze z udziałem cudzoziemców. In: Klaus W, Laskowska K, Rzeplińska I (eds) Przestępczość cudzoziemców. Aspekty prawne, kryminologiczne i praktyczne. Wydawnictwo Naukowe Scholar, Warszawa

Magnuszewska J (2016) Oszustwo zwykłe a oszustwo celne - podobne czy zupełnie inne czyny zabronione? In: Dziembowski R, Pieńkowska M, Oplaksa A (eds) Prawo karne skarbowe wybrane zagadnienia teorii i praktyki. Olszty

Postulski K, Siwek M (2004), Przepadek w polskim prawie karnym. Zakamycze, Kraków

Prusak F, Skowronek G (2018) System Prawa Karnego. Szczególne dziedziny prawa karnego. In: Bojarski M (ed) Prawo karne wojskowe, skarbowe i pozakodeskowe. C.H. Beck, Warszawa

Raglewski J (1998) Stosunek przepisów części ogólnej nowego kodeksu karnego do innych ustaw przewidujących odpowiedzialność karną. Przegląd Sądowy 7-8:19-28

Raglewski J (2007) Penal fiscal code. Commentary. In: Bogdan G, Nita A, Raglewski J, Światłowski AR (2007) Kodeks karny skarbowy: Komentarz. Arche, Gdańsk, p 181

Szajner P (2018) Rynek wyrobów tytoniowych. Stan i perspektywy, Warszawa

Tarach A (2006) Czynności operacyjno-rozpoznawcze. Aspekty kryminalistyczne i prawnodowodowe. Wydawnictwo Uniwersytetu Marii Curie-Skłodowskiej, Lublin

Trząsalska A, Staszyńska M, Krassowska U (2017) Report from a nationwide survey on attitudes towards tobacco consumption, Kantar Public dla Głównego Inspektoratu Sanitarnego. Kantar Public, London

Warylewski J (2005) Wyrób alkoholu na własny użytek. Glosa do uchwały SN z dnia 30 listopada 2004 r., I KZP 23/04. Gdańskie Studia Prawnicze - Przegląd Orzecznictwa 1-2:139-144

Wilk L (2018a) Komentarz do art. 69 Kodeksu karnego skarbowego. Legalis, electronic version, access date: 2019-07-09

Wilk L (2018b) Komentarz do art. 86 Kodeksu karnego skarbowego. Legalis, electronic version, access date: 2019-07-09

Wojciechowski J (2002) Kodeks karny. Komentarz. Piśmiennictwo. Orzecznictwo. Librata, Warszawa

Wróbel W, Zoll A (2017) Kodeks karny. Część szczególna. Komentarz do art. 212-277d, vol. 2. Wolters Kluwer Polska, Warszawa

Zimny M (2017) Akcyza. Komentarz. C. H. Beck, Warszawa

Zontek W (2019) Papierosy domowej produkcji - odpowiedzialność karna w obliczu paralelnej i niespójnej regulacji. Palestra 6:66-82

\section{Reports}

Report on the state of national security 2016, Warsaw, the Ministry of Internal Affairs and Administration

Report on the state of national security 2010, Warsaw, the Ministry of Internal Affairs and Administration

Transcrime. European Outlook on the Illicit Trade in Tobacco Products. Trento: Transcrime Università degli Studi di Trento, 2015

Country Report 2017 - Poland, Task Group Cigarettes 2018

Country Report 2018 - Poland, Task Group Cigarettes 2019

Report from a nationwide survey on attitudes towards tobacco consumption. Kantar Public for the Chief Sanitary Inspectorate, 2017. https://gis.gov.pl/wp-content/uploads/2018/04/PostawyPolaków-do-palenia-tytoniu-Raport-2017.pdf 


\section{Other}

Justification to the government's bill on the Penal Fiscal Code, Sejm of the 3rd term, print No. 1254, http://orka.sejm.gov.pl/Rejestrd.nsf/wgdruku/1146/\$file/1146.pdf

www.statista.com/statistics/415034/cigarette-prices-across-europe/

Konrad Buczkowski Ph.D., is Assistant Professor at the Institute of Law Studies, Polish Academy of Sciences, Poland. His main research interest is criminology, however in addition he has a vast experience in the field of economic criminal law, especially: economic crime, insurance fraud, money laundering, white-collar crime and cybercrime. He is a member of the European Society of Criminology and the Member of the Board of the Polish Society of Criminology.

Paweł Dziekański a Kozminski University graduate, works as a research assistant at the Department of Criminal Law at the Institute of Law Studies of the Polish Academy of Sciences. Previously he was a teaching assistant at the Kozminski University. His research interests focus on criminal procedure. He is an attorney at law, actively working at the private practice.

Open Access This chapter is licensed under the terms of the Creative Commons Attribution 4.0 International License (http://creativecommons.org/licenses/by/4.0/), which permits use, sharing, adaptation, distribution and reproduction in any medium or format, as long as you give appropriate credit to the original author(s) and the source, provide a link to the Creative Commons licence and indicate if changes were made.

The images or other third party material in this chapter are included in the chapter's Creative Commons licence, unless indicated otherwise in a credit line to the material. If material is not included in the chapter's Creative Commons licence and your intended use is not permitted by statutory regulation or exceeds the permitted use, you will need to obtain permission directly from the copyright holder.

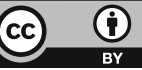

